\title{
Diversity and distribution of subtidal benthic molluscs from the Dampier Archipelago, Western Australia; results of the 1999 dredge survey (DA2/99)
}

\author{
John D. Taylor and Emily A. Glover \\ Department of Zoology, The Natural History Museum, London SW7 5BD, U.K \\ email: j.taylor@nhm.ac.uk \\ emily.glover@dial.pipex.com
}

\begin{abstract}
From a dredge survey of the subtidal fauna of the Dampier Archipelago a total of 422 species of macromolluscs was identified, comprising 227 gastropods, 188 bivalves, four scaphopods and three chitons. Most species were uncommon but abundant taxa included the bivalves Melaxinaea vitrea, Corbula tunicata and C. crassa and the gastropods Herpetopoma atrata and Xenophora solarioides. Community analysis identified eight molluscan assemblages, reflecting the varied and patchy nature of the substrates that ranged from muds and silts to coarse sands, gravel, rubble and rocks. The most species-rich stations were those located inshore at water depths $<10 \mathrm{~m}$. These muddy stations were also notable for the diversity and abundance of suspension-feeding bivalves. Most of the mollusc species identified are distributed widely around tropical Australia and the Indo-West Pacific but a few are endemic to northwestern Australia, including the newly described lucinid bivalve Lamellolucina pilbara.
\end{abstract}

\section{INTRODUCTION}

Although the northwestern Australian shelf is of outstanding biological interest for its suspected high diversity and the relatively high numbers of endemic taxa, the subtidal molluscan fauna is poorly known. Surveys have been made at some locations relatively close to the Dampier Archipelago, including the Montebello and Muiron Islands and Exmouth Gulf, but the results are held in internal reports (Wells, Slack-Smith and Bryce, 1993; Slack-Smith and Bryce, 1996). Most of the published information on molluscs of the Dampier region lies in taxonomic accounts (see Wilson, 19934; Lamprell and Whitehead, 1992; Lamprell and Healy, 1998; and bibliographies) and there have been no published studies of offshore subtidal benthic communities. Faunal surveys of subtidal molluses that have been published concern locations further south along the Western Australian coast such as Shark Bay (Slack-Smith, 1990), the Houtman Abrolhos Islands (Glover and Taylor, 1997; Wells and Bryce, 1997) and Rottnest Island (Glover and Taylor, 1999). The probable high endemism of the molluscan fauna in the Dampier area may be reflected in the number of new species described with variations on "dampier" as part of the name (e.g. Amoria dampieria Weaver, 1960; Conus dampieriensis Coomans and Filmer, 1985).

Recent increasing interest in global diversity patterns is revealing the dearth of data from some parts of the world. Studies of latitudinal gradients in molluscan diversity usually focus on welldocumented continental margins such as the eastern Pacific coast of North America (Roy, Jablonski and Valentine, 2001; Valentine, Roy and Jablonski, 2002). For example, in a study of bivalve global diversity patterns, Crame (2000a, b) has highlighted Australia as an apparent high diversity "hotspot" in the southern hemisphere. Although published information for northern Western Australia is generally lacking, our observations of museum collections and recent fieldwork suggest a serious underestimation of the true diversity. New publications are beginning to confirm this idea (Glover and Taylor, 2001; Middlefart, 2002).

The results of the dredge survey (DA2/99) reported here are first steps toward recording the fauna of a poorly documented area that is of high ecological and biogeographical interest. Faunal surveys such as this provide a baseline for the recognition of future changes in diversity, abundance and distribution of the benthic fauna in relation to such factors as climate change, pollution and other types of environmental disturbance. Additionally, the area is being subjected to increasing levels of environmental disturbance. Factors that may continue to affect the Dampier area include: changes in water circulation patterns induced by the construction of salt extraction ponds; particulate material from iron ore loading; 
dredging of shipping channels; pipeline construction; development of harbour installations and increased sedimentation from terrestrial construction activities.

Although a highly speciose fauna was recorded during this survey, this is just a part of the total molluscan diversity of the area. It does not include the fauna from the extensive and complex intertidal habitats, most of the rich subtidal rocky and coral habitats and the deeper burrowing infauna of subtidal soft substrates. Some of this molluscan fauna will be described in other publications from the area, including the results of the International Marine Biological Workshop held in 2000 (Wells, Walker and Jones, 2003). Additionally, most molluscs of $<5.0 \mathrm{~mm}$ shell length were not retained by the dredge (but some were collected by grab) and are not included in this report.

\section{MATERIALS AND METHODS}

From 14-28 July 1999, a total of 99 dredge stations was sampled in inshore and offshore shallow water around the Dampier Archipelago covering an extensive range of habitats. Most of the archipelago is located within water depths of less than $30 \mathrm{~m}$, with depths of $30-42 \mathrm{~m}$ seaward of the islands. Refer to the Station Lists section of this volume for the dredging expedition (DA2/99) station data and map.

The fauna was sampled with a box-shaped dredge measuring $1200 \mathrm{~mm} \times 330 \mathrm{~mm}$ at the mouth with a $1.0 \mathrm{~cm}$ mesh using either a scooped or raked bottom plate. All dredge runs were of 10 minutes duration at a vessel speed of 2-3 knots except when interrupted by snagging. For some later stations, a sleeve of fly screen was inserted into the dredge to enhance recovery of smaller animals but this made little difference to mollusc recovery. The dredge samples, including sediment, rocks and sponges, were washed through sieves and the molluscs sorted and preserved in $80 \%$ ethanol or $8 \%$ buffered formaldehyde. Blocks of rocks, corals and sponges were broken up to recover cemented epifauna and endobionts.

Although the sampling time at each station was consistently maintained during the survey, an inherent bias in individual mollusc numbers is created by the uneven and patchy nature of the substrates, with the sporadic presence of large boulders, coral blocks, hard bottoms, sponge gardens and gravel. At some stations where sponges and corals were abundant, these were broken up to search for endolithic molluscs but it was not possible to consistently recover all the species from them. Nevertheless, for molluscs inhabiting soft substrates the relative frequency of species recorded in the dredge samples is likely a reflection of their natural abundance.

The molluscs were identified using the reference collections and library at the Natural History
Museum, London. Comparisons were made with type material where appropriate and reference made to original descriptions and illustrations. Voucher material is lodged at the Western Australian Museum and the Natural History Museum, London.

Data were analysed using PRIMER 5 (Plymouth Routines in Marine Environmental Research www.pml.ac.uk/primer/primer-e.htm).

\section{RESULTS}

The molluscan species identified from the dredge stations sampled are listed in systematic order in Table 1. Molluscs recovered only as dead individuals are marked with "*". A total of 422 species of molluscs was identified, comprising 227 gastropods, 188 bivalves, four scaphopods and three chitons. A single inarticulate brachiopod was also recorded. Out of this total, 321 species were recovered live, with around $25 \%$ of bivalves and $17 \%$ gastropods recorded as shells only. The most species-rich families were the Veneridae with 26 species, Turridae (24), Trochidae (21), Muricidae (17) and Tellinidae (11). An estimate of species richness was made using cumulative curves calculated with the Estimates 5 programme (Colwell, 1999). The slope of the species accumulation curve (Figure 1) shows that the sample was not saturated. Extrapolations of total species richness (for the size range of mollusc sampled) gave estimates of between 335-450 species. Our list, including both live and deadcollected (422 species) falls within this range. Total richness is anticipated to be far higher than this because we have not sampled either small species or those with specialised habits such as commensal and parasitic taxa. Bouchet et al. (2002) showed that $33.5 \%$ of the molluscan species in their intensive sampling at New Caledonia have an adult size smaller than $4.0 \mathrm{~mm}$.

The distribution of the 321 species of living molluscs at all stations is shown in Appendix 1 . Most species were rare, with $96(31 \%)$ recorded from single stations and only eight identified from more than 20 stations. A similar pattern is shown for species abundance, with 197 species $(63 \%)$ represented by five or less individuals while 81 $(26 \%)$ of these were recorded only as single specimens. Fifteen species composed about $50 \%$ of the mollusc individuals recovered, with only eight of these forming $41 \%$ of the numbers. Ranked abundances of the most frequent species are shown in Table 2, with some of these illustrated in Figures 2 and 3 . The most abundant mollusc was the shallow burrowing glycymerid bivalve, Melaxinaea vitrea, followed by two other shallow burrowing bivalves, Corbula crassa and C. tunicata. The most abundant gastropod was the hard substrate-living 


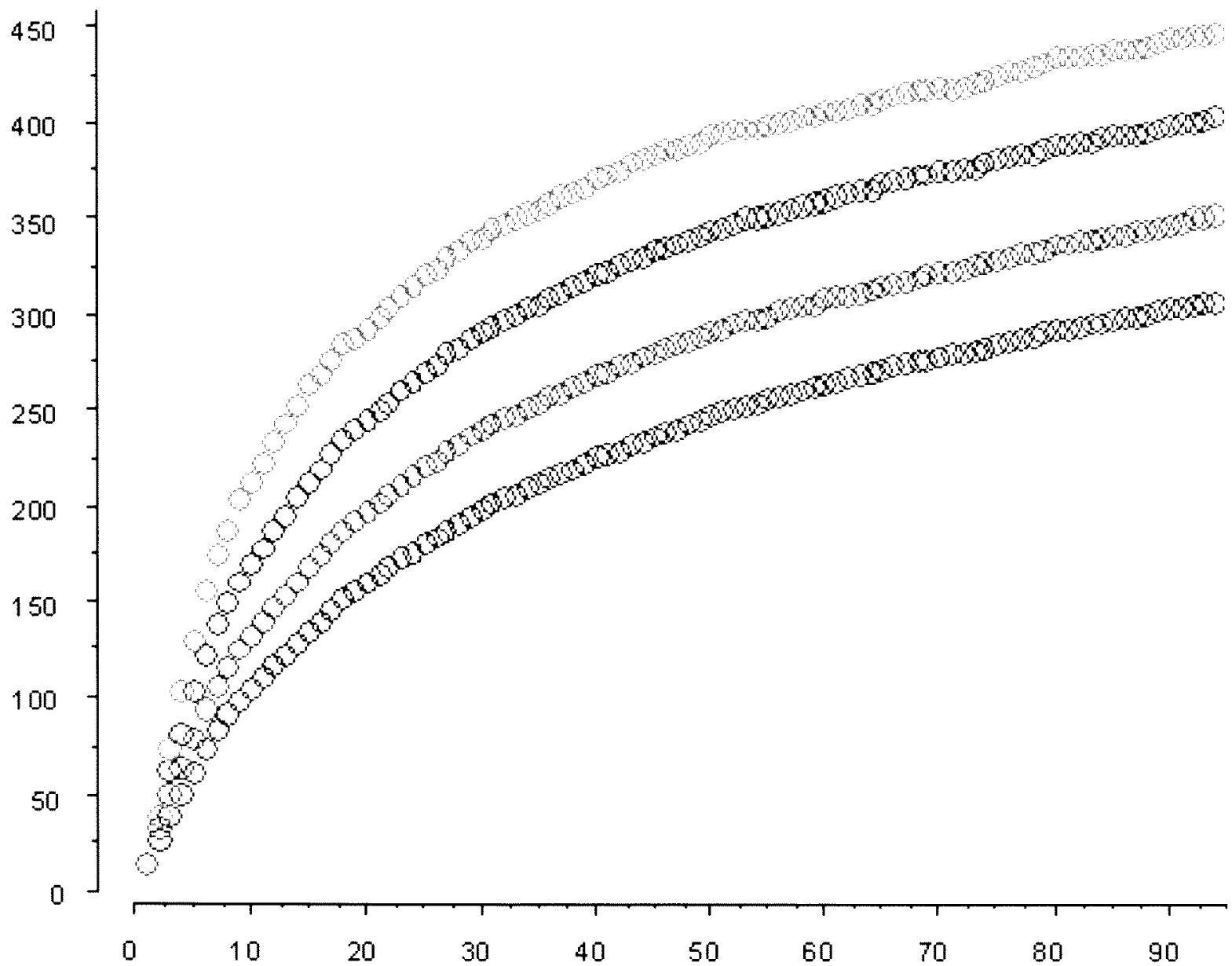

Figure 1 Species accumulation curves calculated using EstimateS 5 (Colwell, 1999). Extrapolations of species richness are given by Jacknife (Jack1 and Jack2) and Bootstrap methods. Data from Appendix 1.

trochid Herpetopoma atrata, with the soft substrate species Xenophora solarioides, Archimediella fastigiata and Strombus vittatus slightly less frequent. A few stations within Dampier Harbour were notable for large numbers of juvenile byssate Trisidos semitorta, an arcid bivalve.

For live molluscs, the most diverse stations (DA2/ 99/73, 66 and 65) were located in Mermaid Strait south of Enderby and East Eaglehawk Islands, in water depths of about $12 \mathrm{~m}$. Station DA2/99/73 was the most species-rich, with a total of 50 taxa. The substrate at this station was largely coarse sand and gravel with a diversity of sponges and free living corals. Species frequent at this station, but less common elsewhere, included Conus dampierensis, three species of Trigonostoma, Tucetona odhneri and Venericardia cardioides. Station DA2/99/ 65 yielded 43 mollusc species and station DA2/99/ 66 had 38 species. A large number of stations elsewhere in the archipelago also yielded more than 30 molluscan species.

Gastropods exhibit the greatest trophic diversity; out of the live collected species $55 \%$ can be classified as predators, $14 \%$ as grazing camivores on sedentary animals including sponges and cnidarians, $5 \%$ are scavengers, $6 \%$ are commensals and ectoparasites, $15.5 \%$ are algal and detritus feeders and $3 \%$ are suspension feeders. The ratio of carnivorous to noncarnivorous species as defined by Valentine et al. (2002) is 3.7. Most of the bivalve species were suspension feeders with few deposit feeding animals and a single chemoautotrophic lucinid.

\section{Community analysis}

More detailed analysis of the sample data using PRIMER indicated a complex mosaic of benthic molluscan assemblages reflecting the highly varied nature of the bottom substrates around the archipelago. Results of the Bray Curtis classification based on the species abundance data (Appendix 1) are shown in Figure 4 and the distribution of stations shown in Figure 5. Typical or indicator species recognised by SIMPER for each of the groups are listed in Table 3. Multiple dimensional scaling (MDS) ordinations of the quantitative data (Figure 6) showed considerable overlap of the C1, C2, C3 and D groups recognised from the dendrogram (Figure 4). However, Groups E, F and $B$ were clearly demarcated confirming their distinctiveness. The distribution and molluscan 


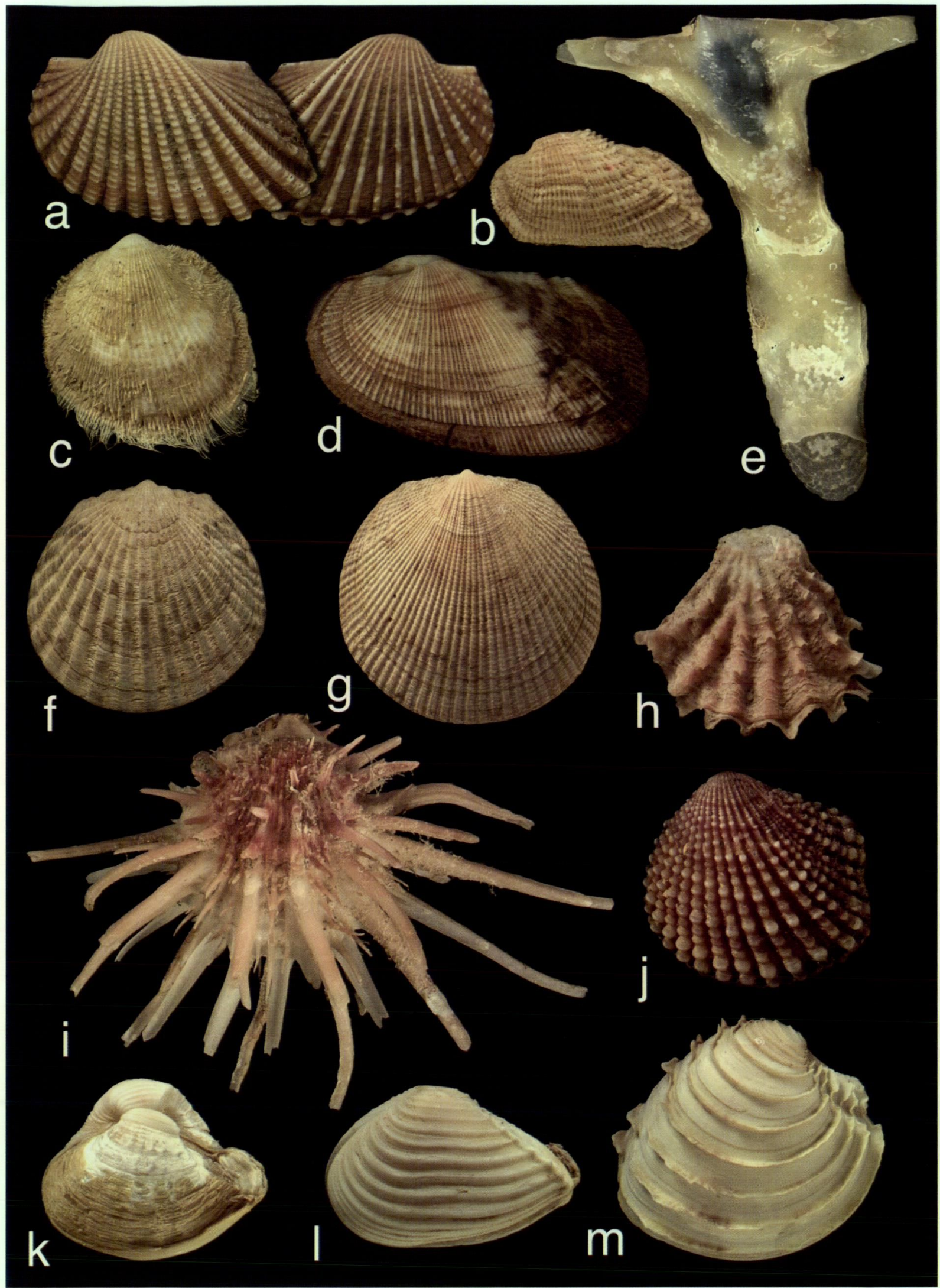

Figure 2 Some common subtidal benthic bivalves of the Dampier Archipelago. (Shell heights in mm). a, Anadara hubbardi (Iredale, 1929) 20.9; b, Acar plicata (Dillwyn, 1817) 10.5; c, Limopsis multistriata (Forskål, 1775) 18.6; d, Trisidos semitorta (Lamarck, 1819) 29.1; e, Malleus albus Lamarck, 1819 108.5; f, Tucetona odhneri Iredale, 1939 24.5; g, Melaxinaea vitrea (Lamarck, 1819) 33.4; h, Plicatula chinensis Mörch, 1853 21.4; i, Spondylus wrightianus Crosse, 1869 56.1; j, Neotrigonia uniophora (Gray, 1847) 16.8; k, Corbula tunicata (Hinds, 1843) 12.7; l, Corbula crassa (Reeve, 1843) 11.9; m, Placamen calophyllum (Philippi, 1836) 30.7. 


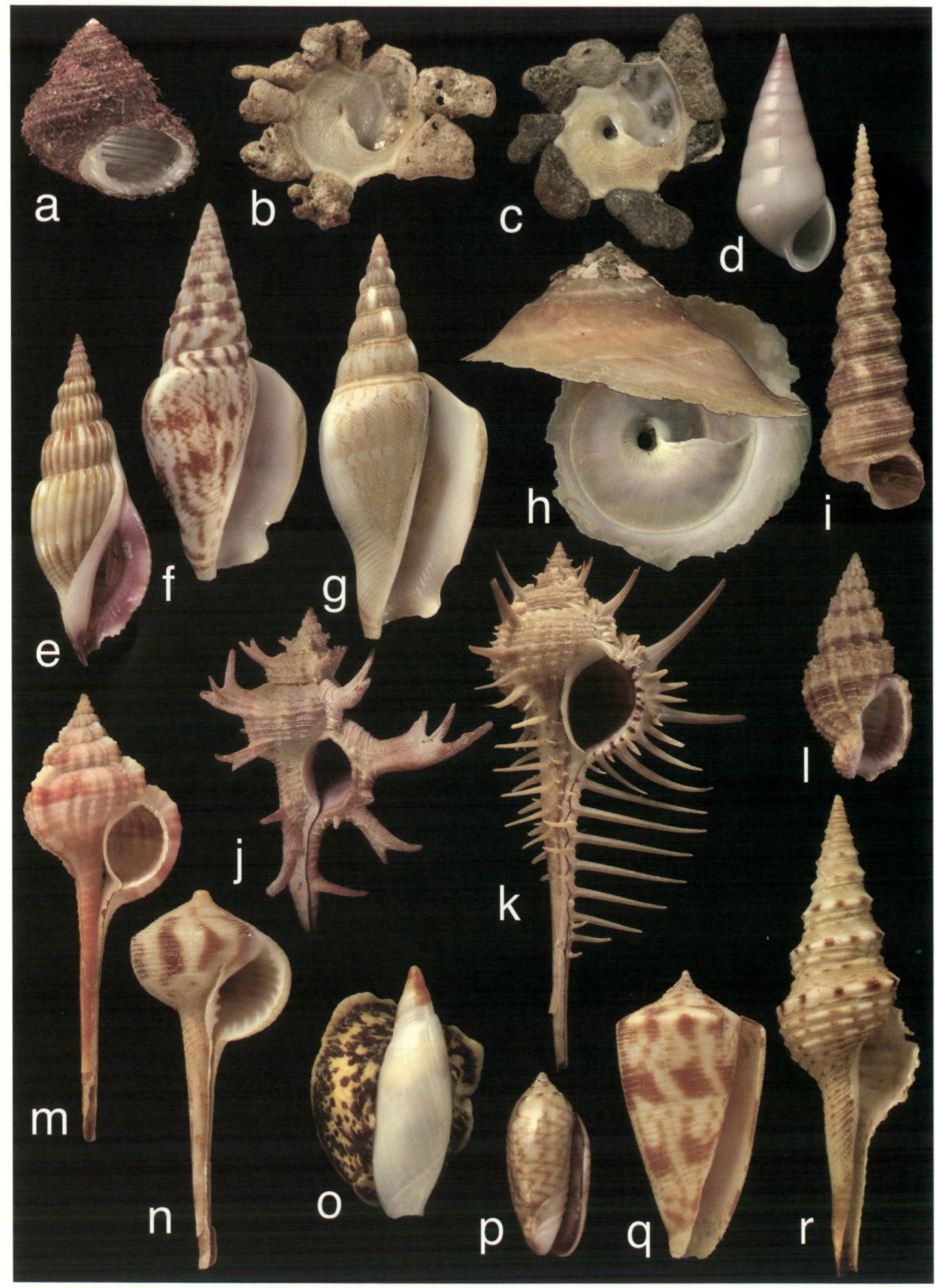

Figure 3 Some common subtidal benthic gastropods from the Dampier Archipelago. (Shell heights in mm). a, Herpetopoma atrata (Gmelin, 1791) 25.3; b, Xenophora cerea (Reeve, 1845) 118.1; c, Xenophora solarioides (Reeve, 1845) 8.7; d, Melanella martinii (A. Adams, 1854) 25.2; e, Rimella cancellata (Lamarck, 1816) 32.7; f, Strombus campbelli Griffith and Pidgeon, 1834 48.4; g, Strombus vittatus Linnaeus, 1758 49.3; h, Xenophora indica (Gmelin, 1791) 35.0; i, Archimediella fastigiata (Adams and Reeve, 1848) 45.6; j, Haustellum multiplicatus (Sowerby, 1895) 53.8; k, Chicoreus cervicornis (Lamarck, 1822) 38.8; 1, Murex pecten soelae Ponder and Vokes, 1988 68.8; $\mathrm{m}$, Phos senticosus (Linnaeus, 1758) 25.9; n, Tudivasum inermis (Angas, 1878) 42.5; o, Ancillista muscae (Pilsbry, 1926) 39.1; p, Oliva brettinghami Bridgman, 1909 11.9; q, Conus dampieriensis Coomans and Filmer, 1985 29.0; r, Lophiotoma indica (Röding, 1798) 42.4. 


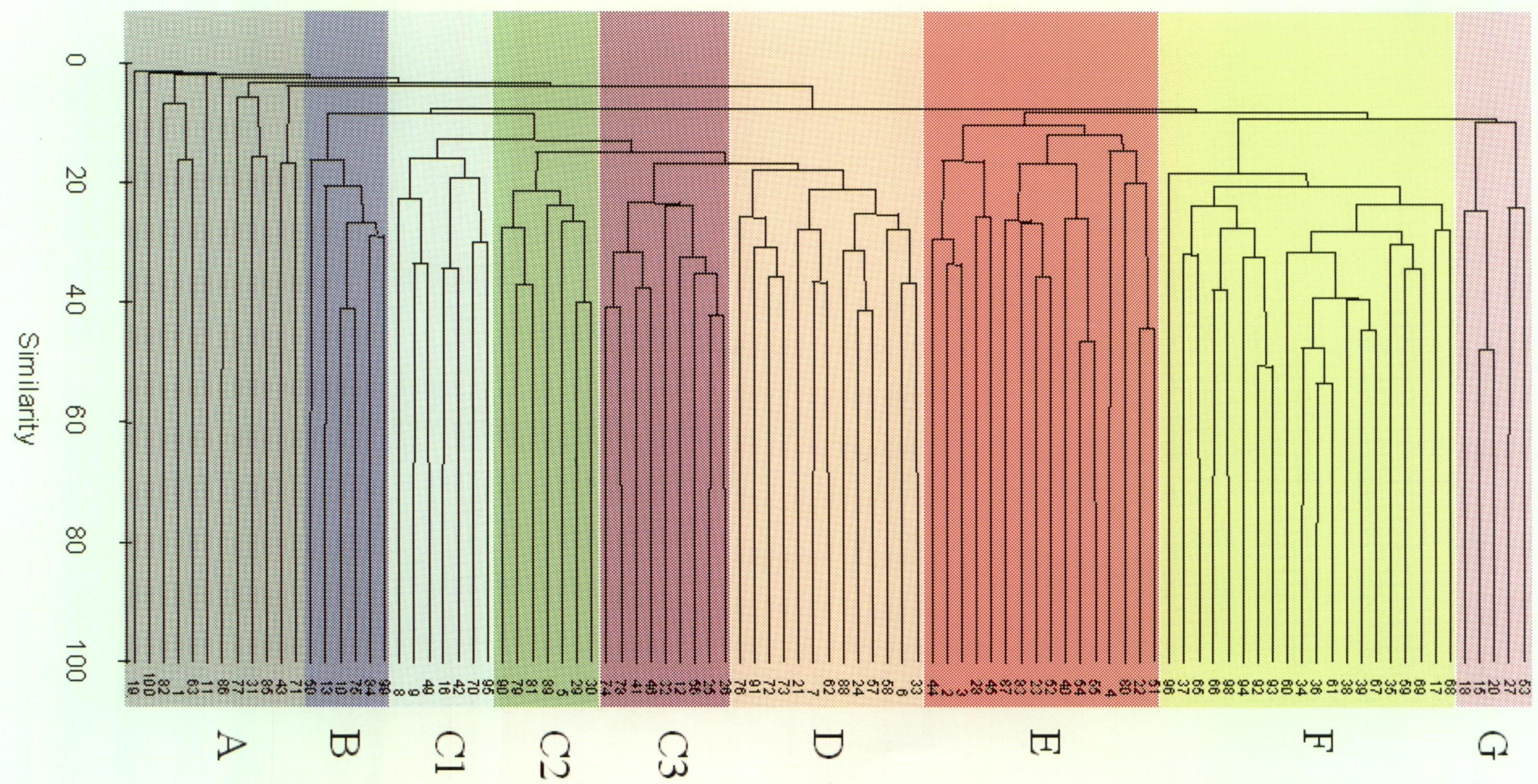

Figure 4 Dendrogram showing classification of Dampier dredge stations based on matrix in Appendix 1. Abundances were root transformed before comparing stations using the Bray-Curtis measure of similarity and the dendrogram produced by group average sorting. 


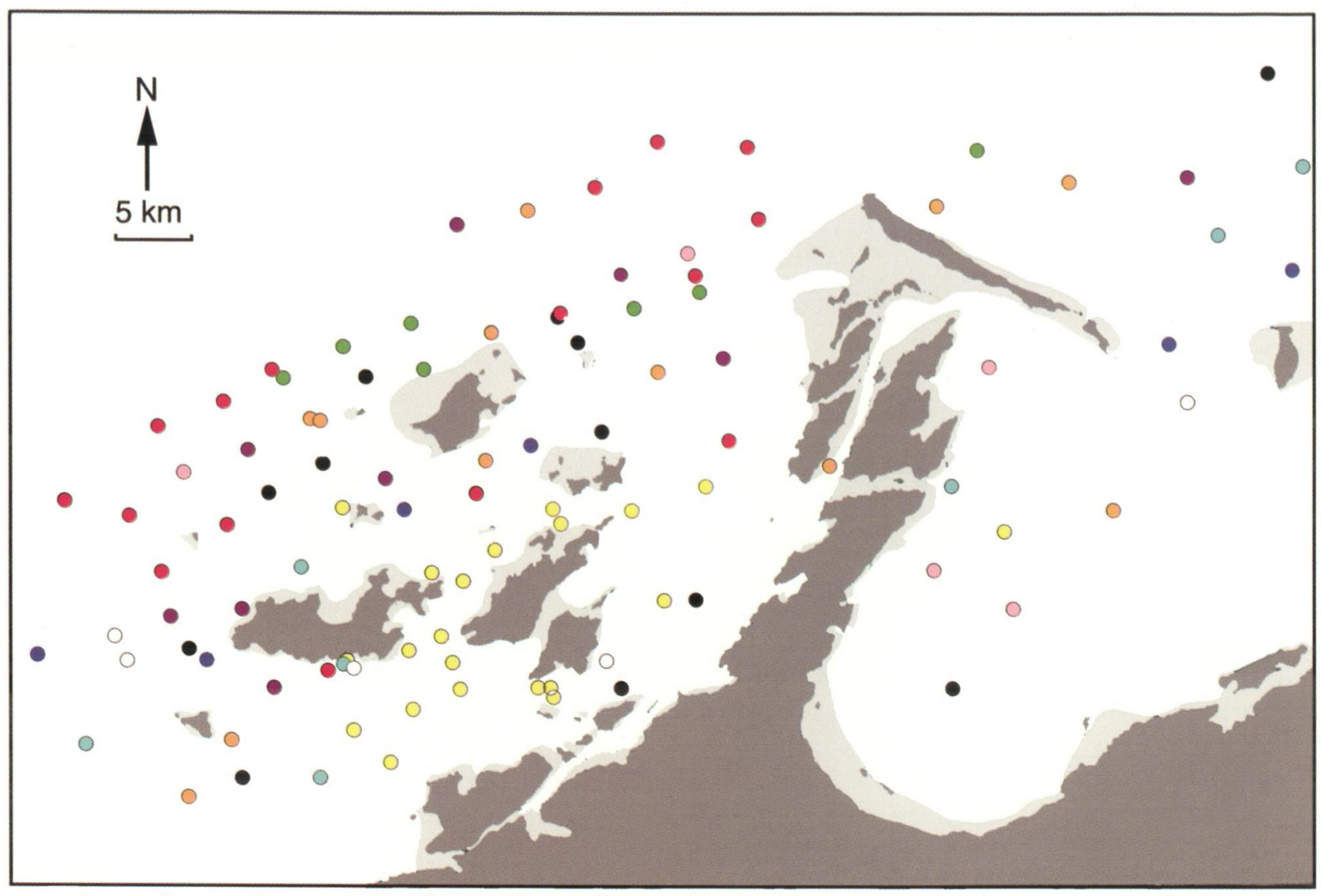

- $\bullet \mathrm{B} \circ \mathrm{C} 1 \cdot \mathrm{C} 2 \bullet \mathrm{C} 3 \circ \mathrm{D} \bullet \mathrm{E} \bullet \mathrm{F} \bullet \mathrm{G}$

Figure 5 Map showing distribution of the stations classified into the groups recognised in Figure 4. Uncoloured circles denote stations at which no live molluscs were recovered (refer to Station Lists).

fauna of the various groups recognised in the analysis are discussed briefly below.

\section{Group A}

This group comprised miscellaneous, unclassified stations from which few molluscs were recovered. These showed extremely low similarity levels and are not considered further.

\section{Group B (stations DA2/99/10, 13, 50, 75, 84, 99)}

This group comprised several widely separated stations with a substrate of rocks, corals and sponges. The fauna was dominated by molluscs usually associated with hard substrates including, amongst the bivalves, the cemented Chama lazarus, the byssate Acar plicata and the sponge nestling Hiatella australis. Characteristic gastropods included the muricids Thais echinata and Cronia avellana and the abundant trochid Hepetopoma atrata.

\section{Group C1 (stations DA2/99/08, 09, 16, 42, 49, 70,} 95)

This group comprised widely separated stations having mixed substrates of sand, rubble, rocks and sponges. The fauna consisted of an assemblage of species characteristic of both soft and hard substrates. Notable species were the shallow burrowing bivalve Corbula tunicata, the rock living gastropod Cronia avellana, the rock boring bivalves Gastrochaena gigantea, Lithophaga malaccana and L. teres, the byssate nestling bivalves Malvufundus regula and Acar plicata and the epifaunal gastropod Herpetopoma atrata.

Group C2 (stations DA2/99/05, 29, 30, 79, 81, 89, 90)

This group comprised stations largely located at depths in excess of $30.0 \mathrm{~m}$ and lying to the seaward of the islands. The substrate consisted of sand and sandy mud with some cobbles and shell debris. The fauna was characterised by an assemblage of sand living gastropods including the predators Tudivasum inermis, Fusinus colus, Gemmula dampieriana and Turricula granobalteus and the deposit feeding and grazing Xenophora solaroides and Strombus plicatus. Common shallow-burrowing, infaunal bivalves included Corbula tunicata, Leionucula superba and Tucetona angusticosta.

Group C3 (stations DA2/99/12, 25, 26, 32, 41, 46, $56,74,78)$

Stations in this group lay largely between the islands of the archipelago with a typical substrate of coarse sand, often with accompanying rubble, 
rocks, abundant bryozoans and sponge patches. Characteristicm molluscs included the shallow burrowing bivalves Corbula tunicata, Placamen tiara, Tucetona angusticosta and Dosinia deshayesi and the epifaunal byssate and cemented species Malleus albus, Plicatula chinensis and Spondylus wrightianaus. Common sand living gastropods included Xenophora solarioides, Ancillista muscae and Strombus campbelli in addition to the hard substrate living species Herpetopoma atrata. This C3 group differed from $\mathrm{C} 2$ notably in the abundance of Corbula tunicata and Malleus albus and the low abundance of Tudivasum inermis.

Group D (stations DA2/99/06, 07, 21, 24, 33, 44, 57, $58,62,72,73,75,88,91)$

This group comprised an assemblage of spatially separated stations either lying between the islands, to the seaward of Legendre Island, or within Nickol Bay. The substrate consisted of coarse sand, gravel and rubble, with rhodololiths, sponges and bryozoans. The molluscan fauna of 161 species was rich and comprised a mixture of animals, including characteristic inhabitants of coarse sands and gravels, together with others associated with hard substrates. Abundant species were the bivalves Corbula tunicata, Tucetona odhneri, Venericardia cardioides and the gastropods Chicoreus cervicornis,
Conus dampierensis, Phos senticosus, Strombus campbelli and Herpetopoma atrata.

Group E (stations DA2/99/02, 03, 04, 22, 23, 28, 40, $44,45,51,52,54,55,80,83,87$ )

Stations in this group lay largely to the seaward of the islands. The substrate consisted of fine or muddy sand with some admixture of cobbles and rocks. The molluscan fauna was largely composed of species normally inhabiting soft substrates, with the gastropods Xenophora solarioides, Natica vitellus, Phos senticosus and the bivalves Melaxinaea vitrea and Limopsis multistriata most abundant. Group E differs from another seaward group (C2) in the much lower abundance of Corbula tunicata and Tudivasum inermis.

Group F (stations DA2/99/17, 34, 35, 36, 37, 38, 39, $59,60,61,65,66,67,68,69,92,93,94,96,98$ )

This group of stations was probably the most well defined geographically and mainly included those located relatively close inshore to the south of Enderby Island and around the Lewis Islands, mostly at water depths $<10.0 \mathrm{~m}$. The substrate mainly consisted of muds, silts and fine sands with some sponges. The molluscan fauna is the most diverse of all groups with 167 species, most of

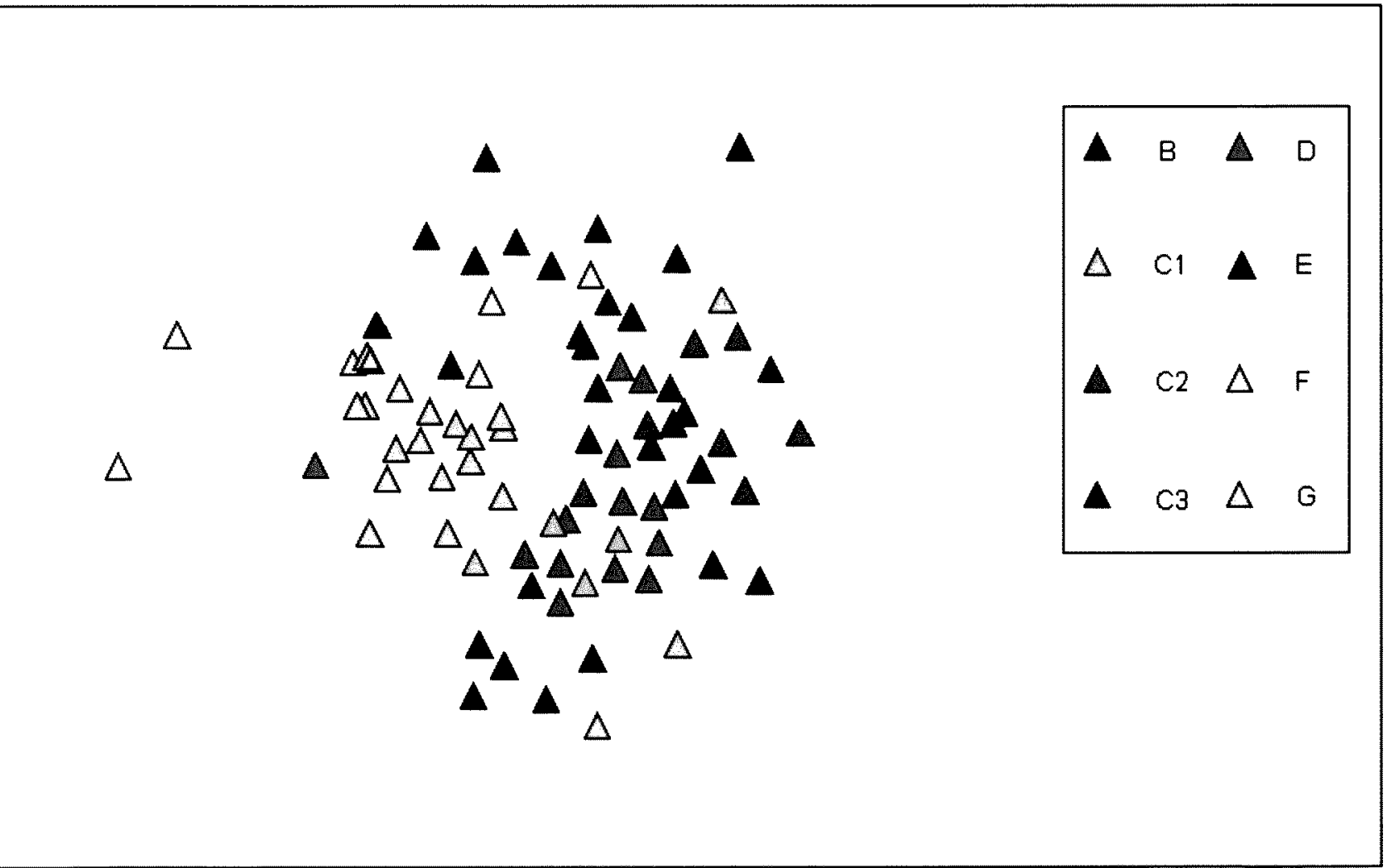

Figure 6 Ordination of stations using multidimensional scaling (MDS) based on the similarity matrix of Figure 4. Identifiying letters for the groups correspond to those of Figure 4 and Table 2. Stations of Group A (miscellaneous stations of low similarity) have been omitted for clarity. 
which were uncommon. The community is dominated by shallow-burrowing infaunal bivalves particularly Melaxinaea vitrea, Corbula crassa, Placamen calophyllum and Anadara hubbardi. A few stations around the southern side of Lewis Islands were notable for high a abundance of juveniles of the byssate semi-infaunal arcid Trisidos semitorta (10.0-15.0 mm shell length).

\section{Group G (stations DA2/99/15, 18, 20, 27, 53)}

This group comprised a small number of stations, three within Nickol Bay. The substrate largely comprised fine muddy sands with abundant ophiuroids and asteroids. Molluscs were generally in low abundance, typified by the shallow burrowing venerid bivalve Placamen calophyllum, and the gastropods Lophiotoma indica and Haustator cingulifera.

\section{Distribution of species}

Even casual study of the dredge results shows that molluscs were not uniformly distributed around the Dampier Archipelago and large differences exist in the composition of the communities along, for example, the onshoreoffshore gradient. Bivalves, for instance, were much more abundant at the shallow inshore stations $(<10 \mathrm{~m})$ with muddy substrates; here an average of around 225 bivalves per station were recovered, contrasting with only 13 per station at the deeper locations seaward of the Archipelago.

Amongst the bivalves, species of the shallowly burrowing Corbulidae showed an interesting pattern (Figure 7). Of the four species found in the survey, $C$. crassa was notably more abundant at inshore, shallow stations with muddy substrates whilst $C$. tunicata was the dominant species outside the islands and also at deeper water stations between them. Three other common shallowburrowing bivalves, Melaxinaea vitrea (Figure 8), Placamen calophyllum (Figure 9) and Trisidos semitorta also showed an inshore distribution similar to that of Corbula crassa. In contrast, for gastropods, those stations seaward of the islands were notable for the abundance of three Xenophora species (Figure 10) along with Tudivasum inermis (Figure 11), Bursa rana and Gemmula dampieriana. All of these species were uncommon or absent at stations among the islands of the archipelago. The long-spined Chicoreus cervicornis was frequent at soft substrate stations between the islands (Figure 12).

It was notable that few molluscs were recovered at stations close to the iron ore loading jetty in Mermaid Sound, suggesting heavy disturbance from ore dust, channel dredging and harbour

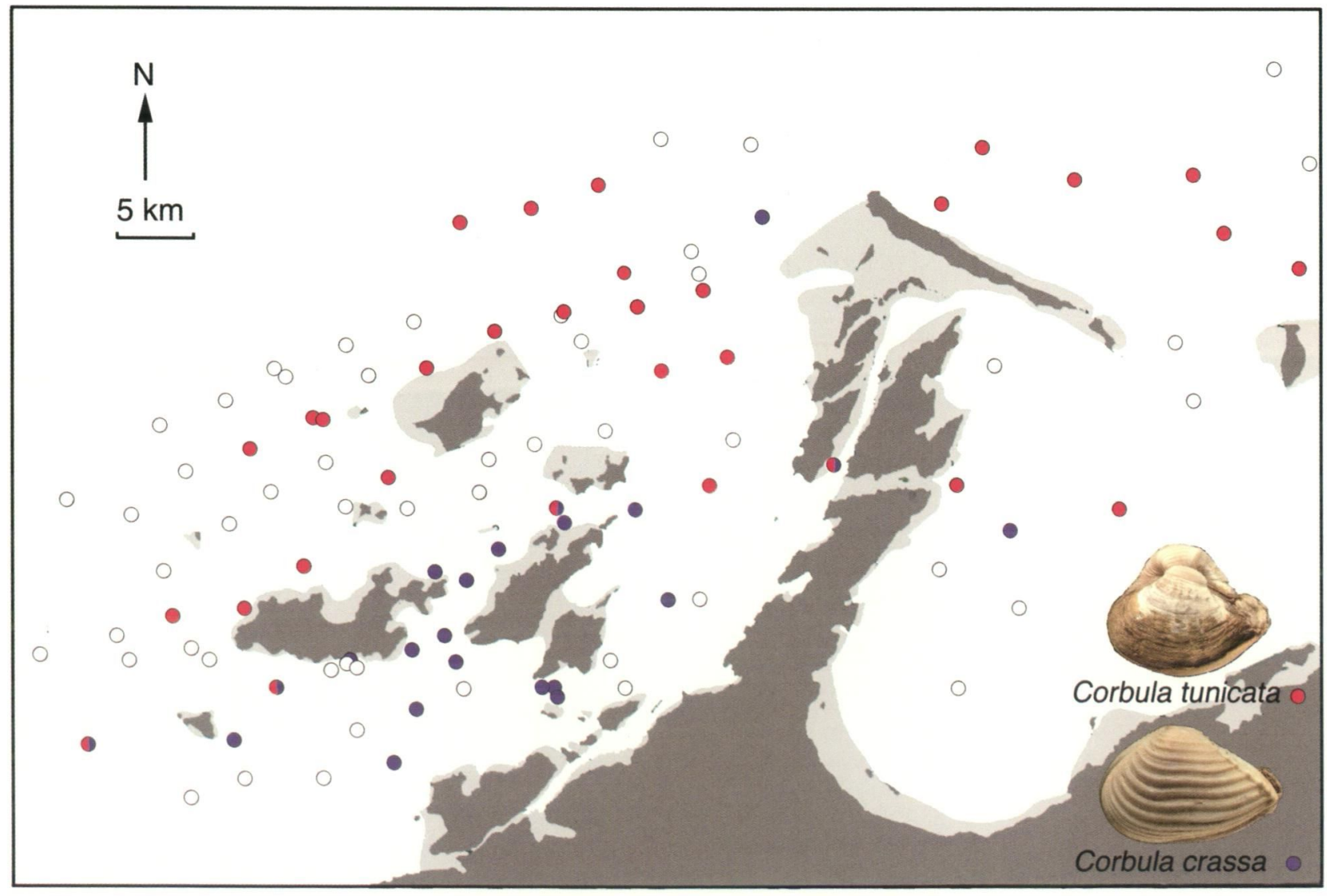

Figure 7 Distribution of Corbula crassa and Corbula tunicata at stations around the Dampier Archipelago. 


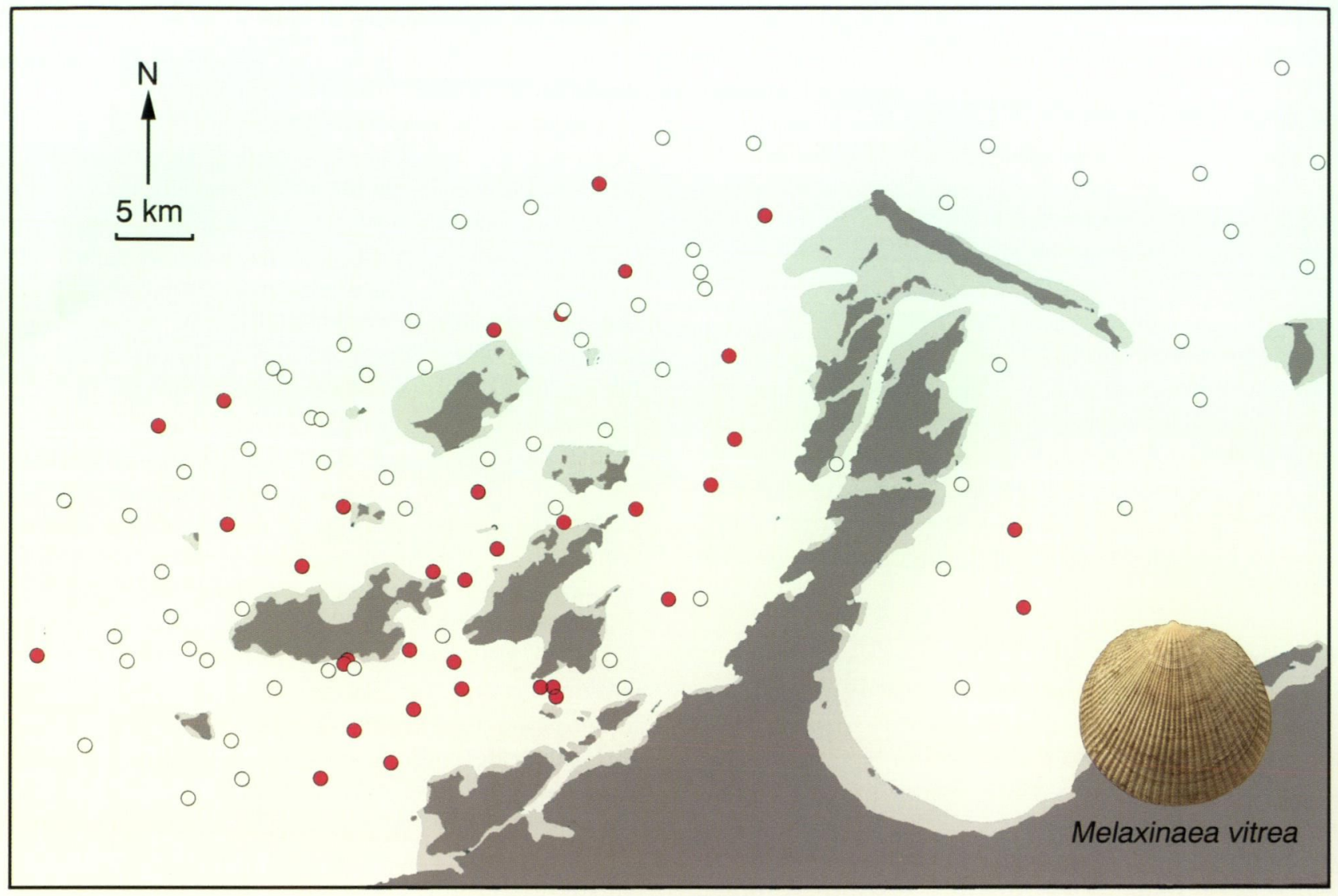

Figure 8 Distribution of Melaxinaea vitrea at stations around the Dampier Archipelago.

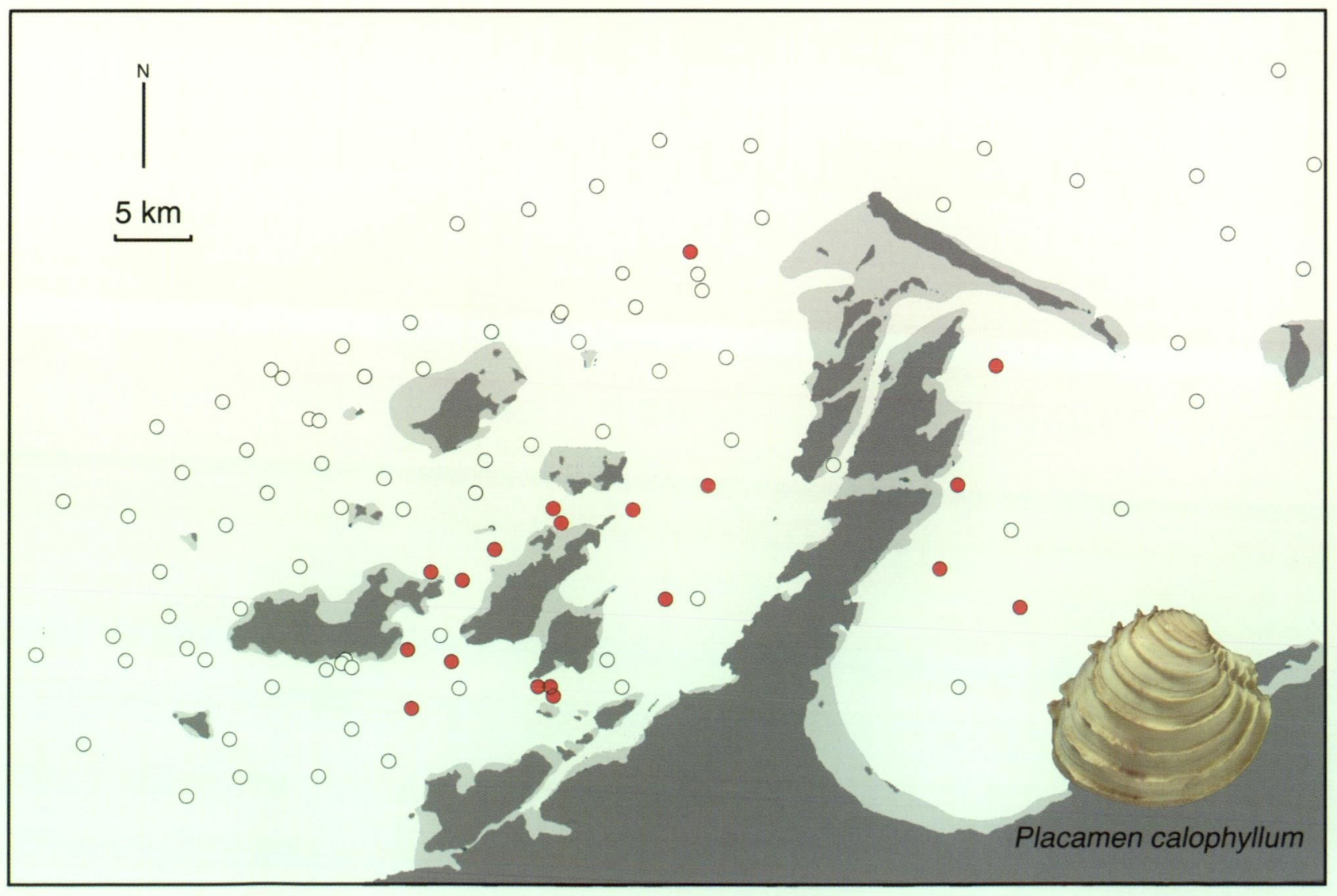

Figure 9 Distribution of Placamen calophyllum at stations around the Dampier Archipelago. 


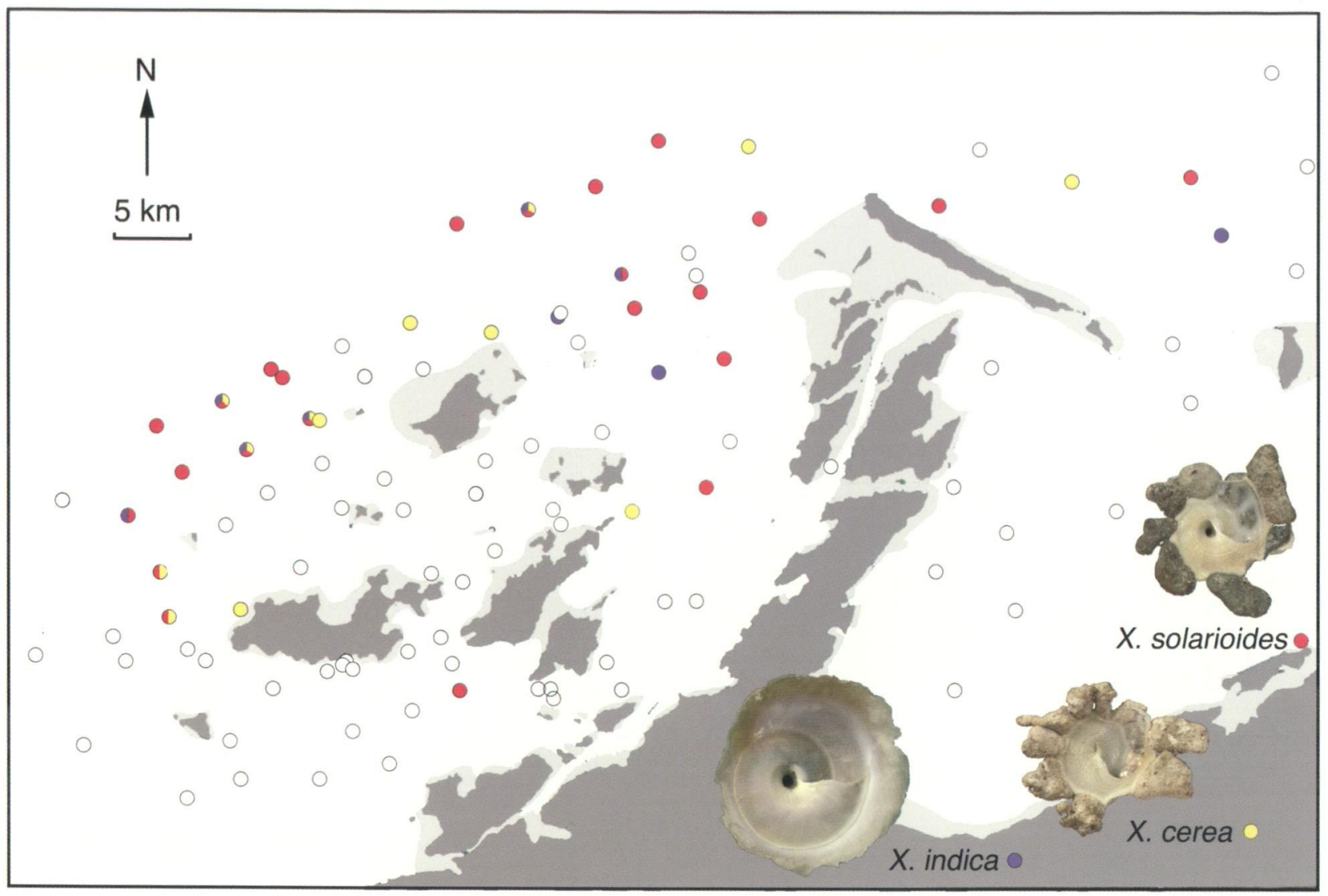

Figure 10 Distribution of Xenophora cerea, X. indica and X. solarioides at stations around the Dampier Archipelago.

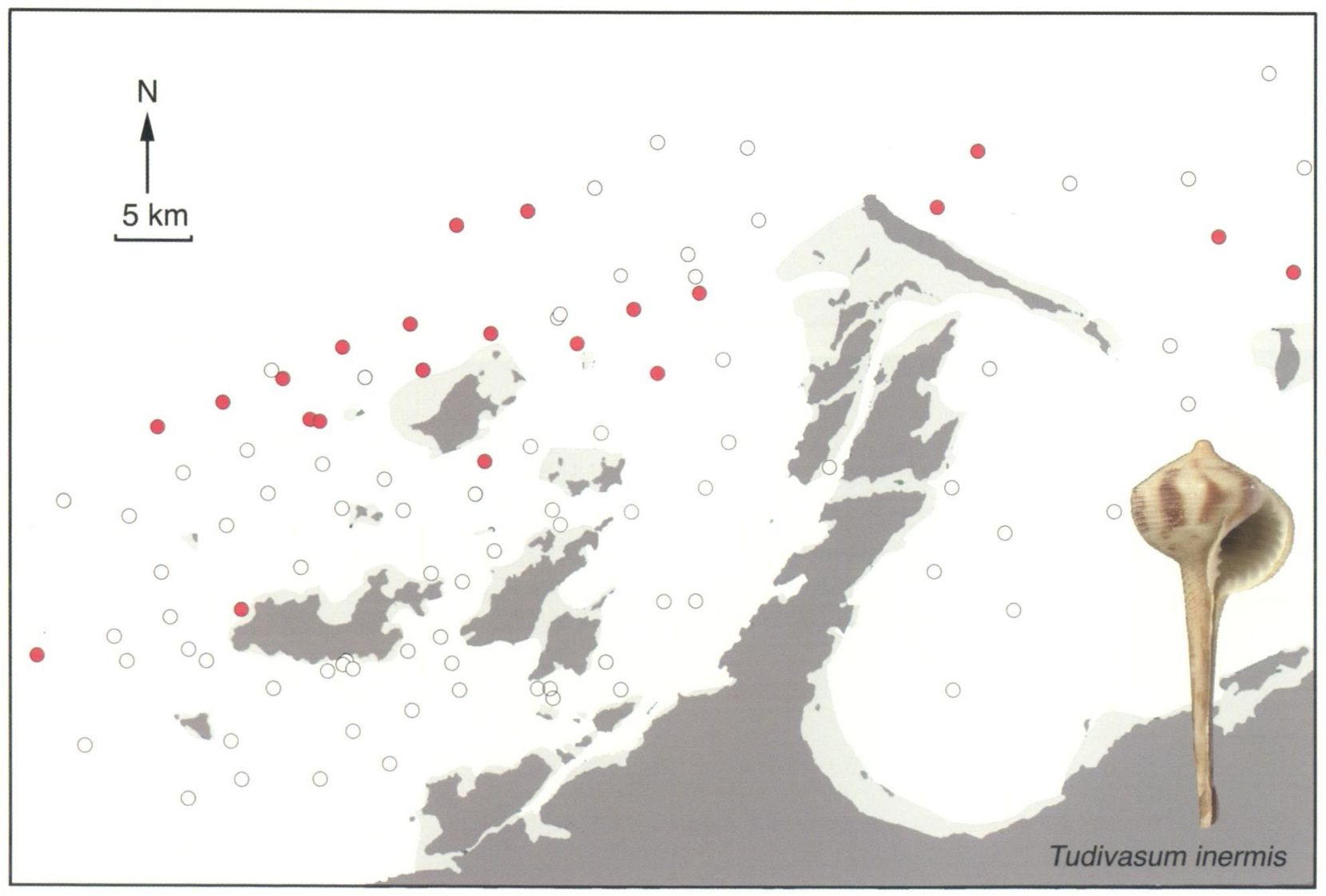

Figure 11 Distribution of Tudivasum inermis at stations around the Dampier Archipelago. 


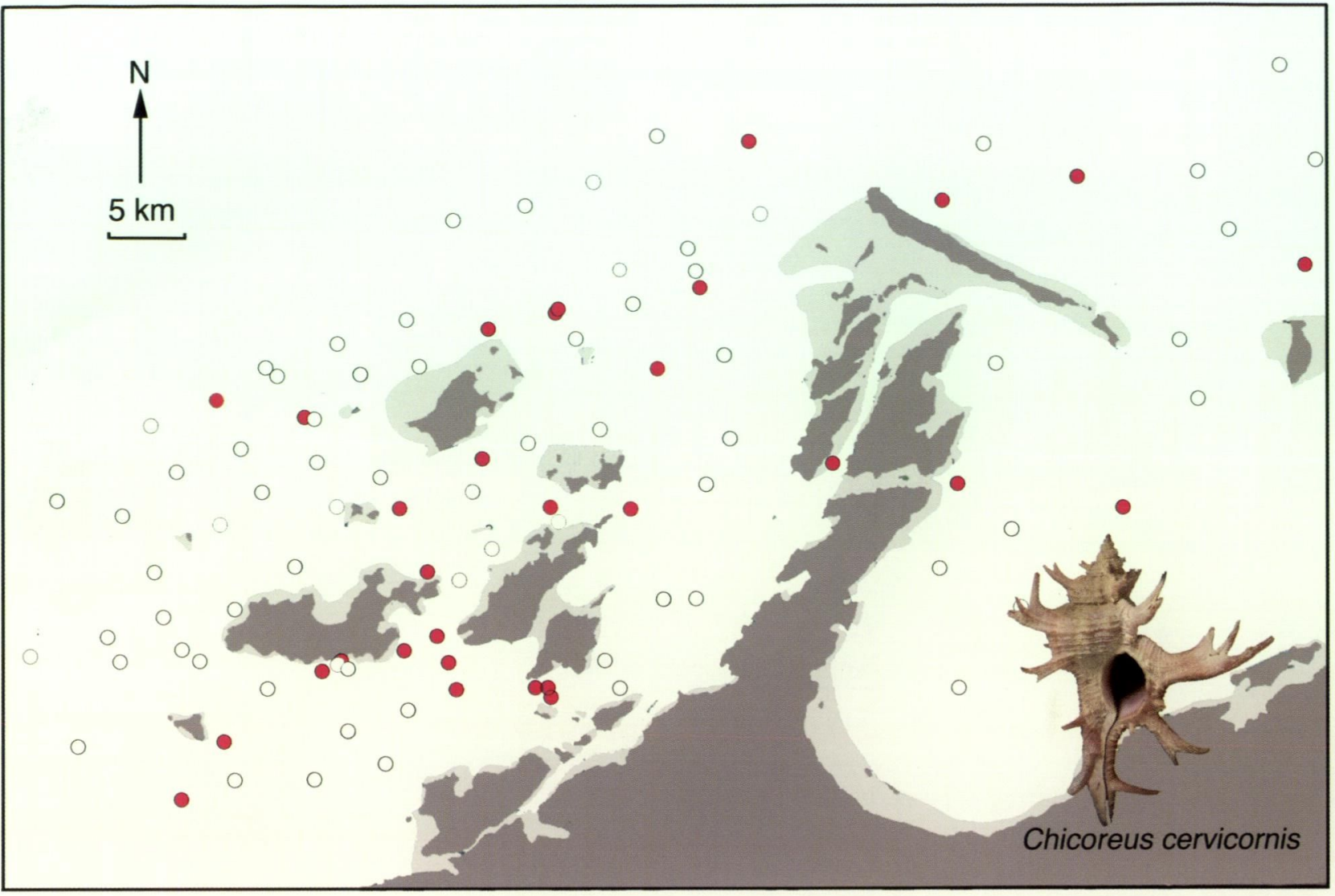

Figure 12 Distribution of Chicoreus cervicornis at stations around the Dampier Archipelago.

activities. This was indicated by the high iron content of the sediment dredged and the low diversity compared with stations at similar depths in Mermaid Strait.

An important discovery was of a previously undescribed species (Lamellolucina pilbara) (Figure 13) representing a new genus of chemosymbiotic lucinid from muddy substrate stations around Enderby Island and in Nickol Bay (Taylor and Glover, 2002). This new species may be endemic as it has not been recognised during extensive studies of museum collections from around Australia and elsewhere.

\section{DISCUSSION}

The molluscan fauna recorded here from subtidal habitats around the Dampier Archipelago represents only a portion of the likely total. Recent studies involving massive sampling effort (Bouchet et al., 2002) have demonstrated that estimates of molluscan species richness on Indo-West Pacific coral reefs have been hugely underestimated, with 2738 species recorded from a $295 \mathrm{~km}^{2}$ coral reef site at New Caledonia. Even in relatively well sampled areas, such as the Florida Keys, species richness has been severely underestimated (Mikkelsen and Bieler, 2000). Nevertheless, despite these limitations, our dredge survey has yielded a species-rich gastropod and bivalve fauna. When these results are combined with the lists of molluscs recorded from the large variety of intertidal and diver-sampled habitats, the fauna of the Dampier area will likely approach the diversity of the tropical Queensland coast. Furthermore, the dredge sampling probably failed to capture many deeper burrowing species. For example, although razor shells (Solen spp) were recovered frequently, only the siphonal tips of live animals were retained in the dredge. Additionally, the micromolluscan fauna has not been studied; Bouchet et al. (2002) suggests that this, including those with specialised commensal and parasitic habits, is likely to account for over one-third of species. Although diversity surveys, such as attempted by Bouchet and his colleagues, are highly labour intensive, there is now a sufficient knowledge of molluscs, based on the all the recent surveys of the Dampier region, to attempt a similar comprehensive estimate of total numbers.

A north-south diversity gradient exists along the Western Australian coast, with the northern tropical fauna becoming attenuated southwards and replaced by the warm temperate fauna, with a transitional overlap zone lying between Cape Leeuwin and North West Cape. Superimposed on this gradient are endemic species forming about $10 \%$ of the total (Wells, 1980; Morgan and Wells, 1991; Wells and Bryce, 1997). Although detailed 


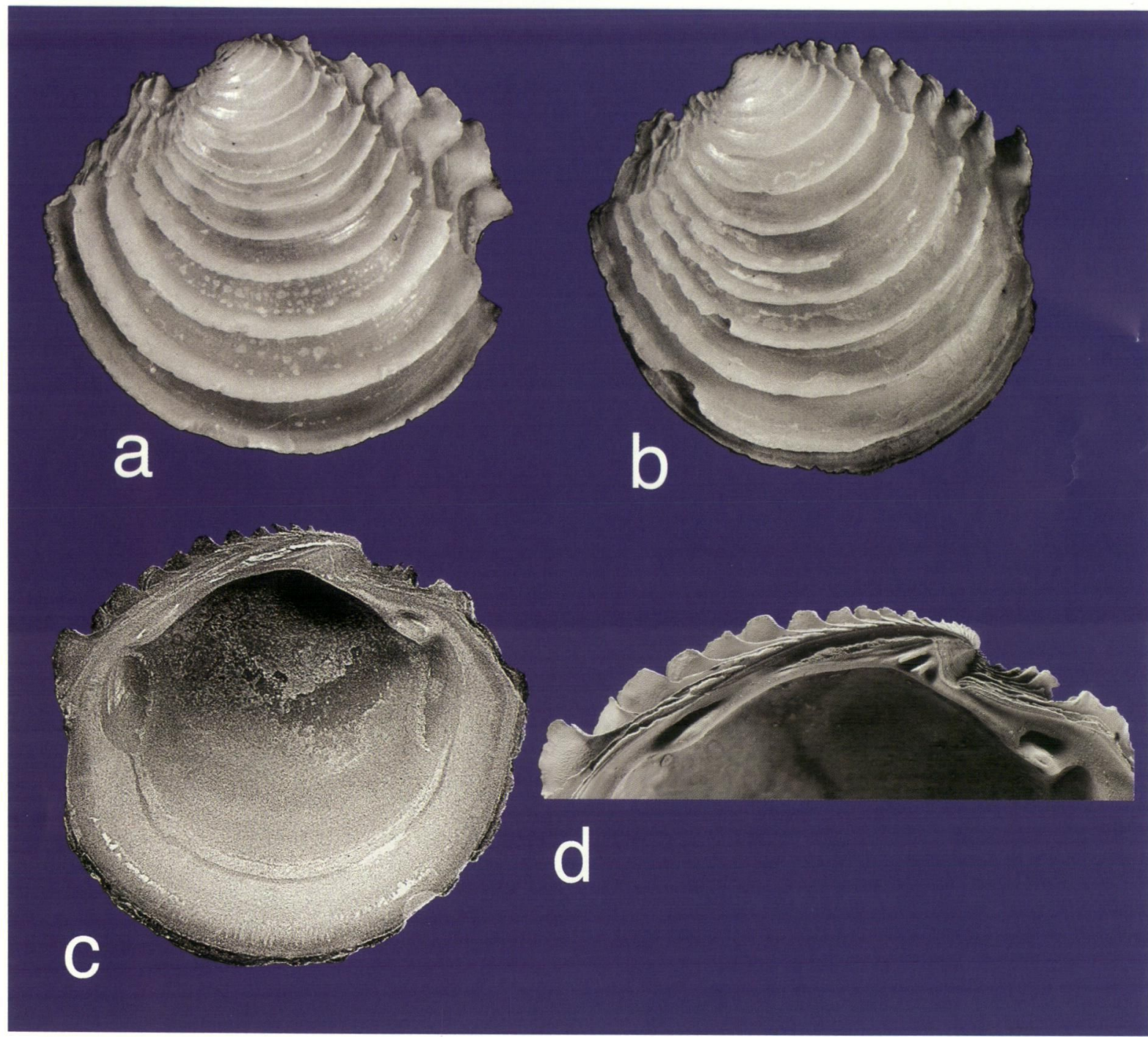

Figure 13 Lamellolucina pilbara Taylor and Glover, 2002, a newly described species of chemosymbiotic lucinid bivalve from the Dampier area. a, left valve of holotype (Western Australian Museum 12064) shell length 14.8mm; $b$, left valve of paratype (WAM 12065) shell length $=14.0 \mathrm{~mm} ; \mathrm{c}$, interior of left valve of holotype; d, detail of hinge teeth of paratype.

distribution patterns for many of the species are not known, it is apparent that the majority of molluscs recovered during the dredge survey are tropical and are more or less widely distributed around the northern coasts of Australia or within the Indo-West Pacific Province. Some species have narrower ranges and are endemic to the area or northwestern Australia. These include the volutid gastropods Amoria dampieria, A. ellioti and A. jamrachi, Cymbiola oblita, the conoideans Gemmula dampieriana and Conus dampieriensis and the lucinid bivalve Lamellolucina pilbara.

Although different habitats were sampled and close comparisons are thus difficult, the fauna dredged from the Dampier area is similar in diversity and composition to that recorded from the Muiron Islands and eastern Exmouth Gulf (SlackSmith and Bryce, 1996). The few reports concerning sub-tidal, soft substrate, mollusc faunas along the
West Australian coast confirm that there is a major diversity gradient, with both the Dampier area and Muiron Islands being significantly more diverse than the more southerly locations. Compared to a similar survey around the Easter Group of the Houtman Abrolhos islands, made in 1994 with the same ship, dredging gear and techniques (Glover and Taylor, 1997), the Dampier stations are much more diverse, comprising 179 live gastropod and 140 live bivalve species compared to 69 and 65, respectively, around the Abrolhos. This compares with a total of 492 species that have been recorded from all habitats around all the Abrolhos Islands (Wells and Bryce, 1997). A similar dredge survey around the more southerly Rottnest Island, near Perth, again using the same ship and gear, but sampling fewer stations, yielded only 47 gastropod and 62 bivalve species (Glover and Taylor, 1999).

One feature of the benthic molluscan 
communities is their patchiness, a response to the highly variable nature of the substrate which varies between mud/silt to sand, gravel, cobbles, rock, coral patches and sponge gardens. The molluscan fauna reflects this variability, with at most stations mixed assemblages of species that normally inhabit both soft and hard substrates. The most spatially circumscribed association we recognised is Group E, comprising the community inhabiting muds, silts and fine sand in the inshore area south of Enderby and Eaglehawk Islands. This is also the most species-rich assemblage, dominated numerically by shallow burrowing bivalves. The marked difference in the abundance of bivalves between the rich inshore sites and the sparsely populated outer stations is probably related to both substrate availability and also to the higher levels of terrigenous nutrient input near-shore.

The most abundant mollusc encountered during the survey was the glycymerid bivalve Melaxinaea vitrea. Glycymerids are usually associated with clean sand and gravel substrates of tropical and temperate continental shelves (Thomas, 1980), as exemplified in Western Australia by the abundance of two species (Glycymeris persimilis and $G$. striatularis) around Rottnest Island (Glover and Taylor, 1999). However, unusually amongst glycymerids, Melaxinaea vitrea is associated around Dampier with the more inshore silts and muds. This species is different in morphology to most other glycymerids, having a highly compressed, discoidal shell with finely beaded ribs, features that may be adaptations to living in muddy substrates. Another glycymerid, Tucetona odhneri, from around Dampier has coarse ribs and is found in the more usual habitat of coarse sands.

In terms of trophic specialization, more than half the species of gastropods can be classified as predators and a further set as having carnivorous habits (faunal grazers, ectoparasites). This matches similar numbers for other tropical continental margins (Taylor and Taylor, 1977) and the ratio of carnivorous to non-carnivorous species of 3.7 attains the levels recorded from tropical sites in the eastern Pacific by Valentine et al. (2002). This high proportion of predatory species, particularly of Neogastroda with highly specialised feeding habits, accounts for much of the high diversity reported for tropical molluscan faunas (Crame, 2001; Valentine et al., 2002).

It is unfortunate that little biological information is available for any of the species recorded in our surveys, even those occurring abundantly. Inferences about life habits are mainly derived from comparisons with species from outside of the region or even from non-tropical areas. Indeed, for some of the common genera, such as Fusinus, Tudivasum, Xenophora, Murex, Chicoreus and Phos, there is little information on feeding habits and ecological role in benthic communities available from anywhere in the Indo-Pacific region. Similarly, for most of the bivalves from the Dampier area, such as the abundant Corbula species and Melaxinaea vitrea, we have no basic biological information which might enable us to understand their interesting distribution patterns around the Dampier Archipelago.

A concluding observation is that the most speciesrich stations identified in this survey lie close inshore between the mainland and Enderby Island, within the area most at risk from anthropogenic disturbance, including onshore development such as salt pond construction, channel dredging and harbour expansion.

\section{ACKNOWLEDGEMENTS}

We are grateful to Diana Jones, Fred Wells and the Western Australian Museum for the opportunity to work in the Dampier area. We thank Theo Berden and the crew of the research vessel Flinders for much assistance and tolerance and to our colleagues on the ship. Shirley Slack-Smith, Melissa Hewitt, Gary Poore and Rachel Scott, for help in sorting and their good-humoured company. Alan Beu advised on identification of tonnoidean gastropods. We are indebted to Jim Chimonides (NHM, London) for his great help with the data analysis and Phil Crabb (NHM) who took the digital images on Figures 2 and 3.

\section{REFERENCES}

Bouchet, P., Lozouet, P., Maestrati, P. and Heros, V. (2002). Assessing the magnitude of species richness in tropical marine environments: exceptionally high numbers of molluses at a New Caledonia site. Biological Journal of the Linnean Society 75: 421-436.

Colwell, R.K. (1999). Estimates: statistical estimation of species richness and shared species from samples, version 5. http://viceroy.eeb.uconn.edu/estimates.

Crame, J.A. (2000a). The nature and origin of taxonomic diversity gradients in marine bivalves. In Harper, E.M., Taylor, J.D. and Crame, J.A. (eds), The evolutionary biology of the Bivalvia. Geological Society, London Special Publications, 177: 347-360.

Crame, J.A. (2000b). Evolution of taxonomic diversity gradients in the marine realm: evidence from the composition of Recent bivalve faunas. Paleobiology 26 : $188-214$.

Crame, J.A. (2001). Taxonomic diversity gradients through geological time. Diversity and Distributions 7 : 175-189.

Glover, E.A. and Taylor, J.D. (1997). Diversity and distribution of subtidal molluses from the outer continental shelf, Houtman Abrolhos Islands, Western Australia. In Wells, F.E. (ed.), The Marine Flora and Fauna of the Houtman Abrolhos Islands, Western Australia: 281-305. Western Australian Museum, Perth. 
Glover, E.A. and Taylor, J.D. (1999). Diversity and distribution of subtidal macromolluscs around Rottnest Island, Western Australia. In Walker, D.I. and Wells, F.E. (eds), The Seagrass Flora and Fauna of Rottnest Island, Western Australia: 101-119. Western Australian Museum, Perth.

Glover, E.A. and Taylor, J.D. (2001). Systematic revision of Australian and Indo-Pacific Lucinidae (Mollusca: Bivalvia): Pillucina, Wallucina and descriptions of two new genera and four new species. Records of the Australian Museum 53: 263-292.

Lamprell, K. and Healy, J. (1998). Bivalves of Australia. Volume 2. Backhuys Publishers, Leiden.

Lamprell, K. and Whitehead, T. (1992). Bivalves of Australia. Volume 1. Crawford House Press, Bathurst.

Mikkelsen, P.M. and Bieler, R. (2000). Marine bivalves of the Florida Keys: discovered biodiversity. In Harper, E.M., Taylor, J.D. and Crame, J.A. (eds), The evolutionary biology of the Bivalvia. Geological Society, London Special Publications, 177: 367-387.

Middelfart, P. (2002). Revision of the Australian Cuninae sensu lato (Bivalvia: Carditoidea: Condylocardiidae. Zootaxa 112: 1-124.

Morgan, G.J. and Wells, F.E. (1991). Zoogeographic provinces of the Humbolt, Benguela and Leeuwin Current Systems. Journal of the Royal Society of Western Australia 74: 59-69.

Roy, K., Jablonski, D. and Valentine, J.W. (2001). Climate change, species range limits and body size in marine bivalves. Ecology Letters 4: 366-370.

Slack-Smith, S.M. (1990). The bivalves of Shark Bay, Western Australia. In Berry, P.F., Bradshaw, S.D. and Wilson, B.R. (eds), Research in Shark Bay. Report of the France-Australe Bicentenary Expedition Committee: 129157. Western Australian Museum, Perth.

Slack-Smith, S.M. and Bryce, C.W. (1996). Part 6 Molluscs. In Hutchins, J.B., Slack-Smith, S.M., Bryce, C.W., Morrison, S.M. and Hewitt, M.A. (eds), Marine
Biological Survey of the Muiron Islands and the eastern Shore of Exmouth Gulf. 64-100. Western Australian Museum, Perth.

Taylor, J.D. and Glover, E.A. (2002). Lamellolucina: a new genus of lucinid bivalve with four new species from the Indo-West Pacific. Journal of Conchology 37: 317336.

Taylor, J.D. and Taylor, C.N. (1977). Latitudinal distribution of predatory gastropods on the eastern Atlantic shelf. Journal of Biogeography 4: 73-81.

Thomas, R.D.K. (1975). Functional morphology, ecology and evolutionary conservatism in the Glycymerididae (Bivalvia). Palaeontology 26: 217-254.

Valentine, J.W., Roy, K. and Jablonski, D. (2002). Carnivore/non-carnivore ratios in northeastern Pacific marine gastropods. Marine Ecology Progress Series 228: 153-163

Wells, F.E. (19800. The distribution of shallow-water marine prosobranch gastropod molluscs along the coastline of Western Australia. Veliger 22: 232-247.

Wells, F.E. and Bryce, C.W. (1997). A preliminary checklist of the marine macromolluscs of the Houtman Abrolhos Islands, Western Australia. In Wells, F.E. (ed.), The Marine Flora and Fauna of the Houtman Abrolhos Islands, Western Australia: 363-383. Western Australian Museum, Perth.

Wells, F.E., Slack-Smith, S.M. and Bryce, C.W. (1993). Molluscs. In Berry, P.F. (ed.), A survey of the marine fauna and habitats of the Montebello Islands, August 1993: 35-66. Western Australian Museum, Perth.

Wells, F.E., Walker, D.I. and Jones, D.S. (eds) (2003). Proceedings of the Eleventh International Marine Biological Workshop: The Marine Flora and Fauna of Dampier, Western Australia. Western Australian Museum, Perth. 1-587 pp (2 volumes).

Wilson, B. 1993-4. Australian marine shells, volumes 1 and 2. Odysssey Publishing, Kallaroo. 
Table 1 List of molluscs dredged from stations around the Dampier Archipelago July 1999. Species indicated by "**” were collected as dead shells only.

\section{BIVALVIA}

\section{Family Nuculidae}

Leionucula superba (Hedley, 1902)

Leionucula cf. cumingi (Hinds, 1843) *

Family Nuculanidae

Nuculana (Scaeoleda) lectilis (Hedley, 1915)

\section{Family Arcidae}

Arca avellana Lamarck, 1819

Arca navicularis Bruguière, 1798

Arca ventricosa Lamarck, 1819

Anadara hubbardi (Iredale, 1929)

Anadara sp. B ?crebricostata (Reeve, 1844) *

Barbatia sp. A ?foliata (Forskål, 1775)

Barbatia cf. bistrigata Dunker, 1866

Trisidos semitorta Lamarck, 1819

Acar plicata (Dillwyn, 1817)

Acar cf. riculata (Gmelin, 1791)

Family Cucullaeidae

Cucullaea labiata (Lightfoot, 1786)

Family Glycymerididae

Glycymeris dampieriensis Matsukuma, 1984 *

Tucetona angusticosta Lamprell and Whitehead, 1990

Tucetona auriflua (Reeve, 1843) *

Tucetona odhneri Iredale, 1939

Melaxinaea vitrea (Lamarck, 1819)

Family Limopsidae

Limopsis multistriata (Forskål, 1775)

Family Mytilidae

Stavelia subdistorta Récluz, 1852

Modiolus cf. barbatus (Linnaeus, 1758)

Modiolus philippinarum Hanley, 1843

Modiolatus elongatus (Swainson, 1821)

Septifer bilocularis (Linnaeus, 1758)

Musculus cf. cumingianus Reeve, 1857

Botula silicula Lamarck, 1853

Gregariella otteri (Iredale, 1939)

Lithophaga lima (Lamy, 1919)

Lithophaga malaccana (Reeve, 1858)

Lithophaga teres Philippi, 1846

\section{Family Pteriidae}

Pteria cookei Lamprell and Healy, 1997

Pteria falcata (Lamarck, 1819)

Pteria lata (Gray, 1845)

Pteria penguin (Röding, 1798)

Pteria sp.

Pinctada maxima (Jameson, 1901)

Electroma spadicea (Dunker, 1852)

Pterelectroma physoides (Lamarck, 1819)

Family Malleidae

Malleus albus Lamarck, 1819

Malvufundus regula (Forskål, 1775)

Vulsella vulsella (Linnaeus, 1758)

Family Isognomonidae

Isognomon legumen (Gmelin, 1790)
Family Pinnidae

Pinna deltoides Menke, 1843 *

Atrina pectinata (Linnaeus, 1767)

Pinna sp. juveniles

\section{Family Pectinidae}

Amusium pleuronectes (Linnaeus, 1758)

Pecten cf. excavatus Anton, 1839 *

Annachlamys flabellata (Lamarck, 1819)

Excellichlamys histrionica (Gmelin, 1791)

Decatopecten strangei (Reeve, 1852)

Complicachlamys dringi (Reeve, 1853)

Mimachlamys "scabricostata" (Sowerby, 1915) species group

Cryptopecten nux (Reeve, 1853)

Hemipecten forbesianus Adams and Reeve, 1849

\section{Family Spondylidae}

Spondylus albibarbatus Sowerby, 1847

Spondylus eastae Lamprell, 1992

Spondylus victoriae Sowerby, 1843 *

Spondylus wrightianus Crosse, 1869

Spondylus sp. A*

Spondylus sp. B*

Spondylus sp. C*

Family Limidae

Lima nimbifer Iredale, 1924

Limatula ponderi Fleming, 1978*

Limaria fragilis (Gmelin, 1791)

Limariasp.

Ctenoides annulata (Lamarck, 1819) *

\section{Family Ostreidae}

Hyotissa hyotis (Linnaeus, 1758)

Parahyotissa numisma (Lamarck, 1819) *

Dendrostrea folium (Linnaeus, 1758)

Planostrea ?pestigris (Hanley, 1846) juveniles

Alectryonella plicatula (Gmelin, 1791)

\section{Family Plicatulidae}

Plicatula australis Lamarck, 1819

Plicatula chinensis Mörch, 1853*

Family Anomidae

Monia sp.

Family Placunidae

Placuna (Ephippium) lobata (Sowerby, 1871)

Family Trigoniidae

Neotrigonia bednalli (Verco, 1907)

Neotrigonia uniophora (Gray, 1847)

Family Lucinidae

Lamellolucina pilbara Taylor and Glover, 2002

Cardiolucina pisiformis (Thiele, 1930)

Callucina (Pseudolucinisca) lacteola (Tate, 1897) *

Anodontia bullula (Reeve, 1850) *

Anodontia sp.

Divaricella irpex (Smith, 1885) *

Family Ungulinidae

Diplodonta sublateralis (Smith, 1884) * 
Diplodonta cf. holosphaera Melvill, 1899

Diplodonta sp. *

Family Galeommatidae

Scintilla cf. aurantia (Deshayes, 1835)

Scintilla spp

Galeomma sp.

Ephippodontasp.

Family Lasaeidae

Lepton sp.

Kellia sp. *

Family Crassatellidae

Talabrica ziczac (Reeve, 1842)

Eucrassatella pulchra (Reeve, 1842)

Salaputium rhomboides (Smith, 1885)

Family Carditidae

Venericardia cf. cardioides (Reeve, 1843)

Cardita crassicosta Lamarck, 1819

Cardita cf. incrassata Sowerby, 1825

Cardita variegata Bruguière, 1792

\section{Family Chamidae}

Chama asperella Lamarck, 1819

Chama lazarus Linnaeus, 1758 *

Chama pacifica Broderip, 1834

Chamasp.

\section{Family Cardiidae}

Vepricardium multispinosum (Sowerby, 1838)

Nemocardium bechei (Reeve, 1840)

Ctenocardia fornicata (Sowerby, 1840)

Ctenocardia perornata (Iredale, 1929) *

Acrosterigma attenuatum (Sowerby, 1841) *

Acrosterigma biradiatum (Bruguière, 1789)

Acrosterigma dampierense Wilson and Stevenson, 1977

Acrosterigma rosemariensis Wilson and Stevenson, 1977

Vasticardium elongatum (Bruguière, 1789) *

Lunulicardia retusa (Linnaeus, 1767)

Lyrocardium lyratum (Sowerby, 1834) *

Fulvia aperta (Bruguière, 1798) *

\section{Family Mactridae}

Mactra incarnata Reeve, 1854

Lutraria australis (Reeve, 1854) *

Oxyperas triangularis (Lamarck, 1819) *

\section{Family Trapeziidae}

Coralliophaga coralliophaga (Gmelin, 1791)

\section{Family Tellinidae}

Arcopella cf. isseli (H. Adams, 1871)

Arcopaginula inflata (Gmelin, 1791)

Clathrotellina elegantissima (Smith, 1885)

Clathrotellina pretium (Salisbury, 1934)

Tellinella asperrima (Hanley, 1844)

Tellinella cf. radians (Deshayes, 1854) *

Tellinella verrucosa (Hanley, 1844)

Angulus emarginata (Sowerby, 1825) *

Tellinides ovalis (Sowerby, 1825)

Pinguitellina casta (Hanley, 1844)

Leporimetis spectabilis (Hanley, 1844) *

Macoma (Psammacoma) candida (Lamarck, 1818) *

Merisca piratica (Hedley, 1918) *
Family Semelidae

Semele casta A. Adams, 1853

Family Psammobiidae

Gari anomala (Deshayes, 1855)

Gari rasilis (Melvill and Standen, 1899) *

Gari pulcherrima (Deshayes, 1855) *

Gari maculosa (Lamarck, 1818)

Gari amethystus (Wood, 1815)

Family Solecurtidae

Solecurtus sulcatus (Dunker, 1861) *

Solecurtus sp. *

Azorinus minutus (Dunker, 1861) *

\section{Family Solenidae}

Ensiculus cultellus (Linnaeus, 1758)

Solen aureomaculatus Habe, 1964 *

Solen kajiyamai Habe, 1964 *

Solen sp. undescribed species

\section{Family Veneridae}

Antigona chemnitzii (Hanley, 1844)

Antigona lamellaris Schumacher, 1817

Globivenus embrithes (Melvill and Standen, 1899)

Sunetta contempta Smith, 1891

Placamen calophyllum (Philippi, 1836)

Placamen tiara (Dillwyn, 1817)

Dosinia deshayesï A. Adams, 1855

Dosinia histrio (Gmelin, 1790) *

Dosinia cf. juvenilis Gmelin 1791

Dosinia scalaris (Menke, 1843) *

Dosinia cf. subalata Smith, 1916

Callista cf. roseotincta (Smith, 1885)

Tawera laticostata (Ohdner, 1917)

Paphia gallus (Gmelin, 1791)

Paphia semirugata (Philippi, 1847)

Circe scripta (Linnaeus, 1758)

Pitar cf. trevori Lamprell and Whitehead, 1990

Pitar sp. A

Pitarsp. B*

Pitarina sp. $\mathrm{C}^{*}$

Pitar (Hyphantosoma) sp. juvenile*

Lioconcha fastigiata (Sowerby, 1851)

Tapes platyptycha Pilsbry, 1901

Callista (Costacallista) planatella (Lamarck, 1818)

Clementia papyracea (Gray, 1825) *

Irus irus (Linnaeus, 1758)

\section{Family Corbulidae}

Corbula crassa Reeve, 1843

Corbula macgillivrayi Smith, 1885

Corbula taheitensis Lamarck, 1818

Corbula tunicata Hinds, 1843

\section{Family Pholadidae}

Parapholas quadrizonata (Spengler, 1791)

Jouannetia cumingi (Sowerby, 1850)

Family Gastrochaenidae

Gastrochaena dentifera Dufo, 1840

Gastrochaena gigantea Deshayes, 1830

Spengleria plicatilis (Deshayes, 1855)

Cucurbitula cymbium (Spengler, 1783)

Family Hiatellidae

Hiatella australis (Lamarck, 1818) 
Table 1 (cont.)

Family Sphenidae

Sphenia cf. rueppellii A. Adams, 1851

Family Laternulidae

Laternula cf. anatina (Linnaeus, 1758)

Family Myochamidae

Myadora pavimenta Hedley, 1912

Family Cleidothaeridae

Cleidothaerus plicifera (Ohdner, 1917)

Family Clavagellidae

Brechites vaginiferus australis (Chenu, 1843) *

Brechites philippinenis (Chenu, 1843) *

\section{SCAPHOPODA}

Laevidentalium longitrorsum (Reeve, 1842)

Dentalium exmouthensis Lamprell and Healy, 1998

Dentalium cf. octangulatum Donovan, 1803

Dentalium sp. *

\section{GASTROPODA}

Family Fissurellidae

Diodora jukesii (Reeve, 1850)

Diodora singaporensis (Reeve, 1850)

Diodora ticaonica (Reeve, 1850)

Emarginula inciscura (Adams, 1853) *

Scutus unguis (Linnaeus, 1758)

Tugali cicatricosa A. Adams, 1851

Family Trochidae

Angaria delphinus (Linnaeus, 1758) *

Calliostoma similiare (Reeve, 1863) *

Calliostoma (Astele) monile (Reeve, 1863)

Calthalotia sp.

Calthalotia mundula (Adams and Angas, 1864)

Clanculus bicarinatus Angas, 1880

Clanculus comarilis (Hedley 1912)

Euchelus sp.

Herpetopoma atrata (Gmelin, 1791)

Herpetopoma instricta (Gould, 1849)

Liotina crassibasis Smith, 1880

Liotina peronii (Kiener, 1839) *

Microtis tuberculata (Adams, 1850) *

Monilea callifera (Lamarck, 1822)

Notogibbula sp.

Stomatia phymotis Helbling, 1779

Talopena vernicosa (Gould, 1861) *

Trochus histrio Reeve, 1848 *

Trochus maculatus Linnaeus, 1758 *

Trochus schlueteri Sowerby, 1894

Turcica maculata (Brazier, 1877)

Family Turbinidae

Astralium stellare (Gmelin, 1791)

Turbo haynesi Preston, 1914

Family Cerithiidae

Cerithium novaehollandiae (Adams and Sowerby, 1855)

Cerithium torresi Smith, 1844

Rhinoclavis articulata (Adams and Reeve, 1850)

Rhinoclavis kochi (Philippi, 1848)
Family Calyptraeidae

Cheilea equestris (Linnaeus, 1758) *

Crepidula aculeata (Gmelin, 1791)

Family Capulidae

Capulus danieli (Crosse, 1858) *

Family Hipponicidae

Hipponix sp.

Family Turritellidae

Archimediella fastigiata (Adams and Reeve, 1848)

Haustator cingulifera (Sowerby, 1825)

Family Vanikoridae

Vanikoro cancellata (Lamarck, 1822)

Family Siliquariidae

Siliquaria ponderosa (Mörch, 1860)

Siliquaria sp. A*

Siliquaria sp. B

Family Vermetidae

Vermetus sp.

Family Strombidae

Strombus campbelli Griffith and Pidgeon, 1834

Strombus dilatatus Swainson, 1821

Strombus plicatus pulchellus Reeve, 1851

Strombus vittatus vittatus Linnaeus, 1758

Terebellum terebellum (Linnaeus, 1758)

Rimella cancellata (Lamarck, 1816)

Family Xenophoridae

Xenophora indica (Gmelin, 1791)

Xenophora cerea (Reeve, 1845)

Xenophora solarioides (Reeve, 1845)

\section{Family Ovulidae}

Hiatovolva depressa (Sowerby, 1875)

Primovulua striatula (Sowerby, 1828)

Diminovula cf. alabaster (Reeve, 1865)

Prionovula cavanaghi (Iredale, 1931)

Phenacovolva tokioi Cate, 1973 *

Phenacovolva haynesi (Sowerby, 1889)

Phenacovolva philippinarum (Sowerby, 1848)

Volva volva (Linnaeus, 1758) *

Family Cypraeidae

Cypraea gracilis Gaskoin, 1849

Cypraea miliaris Gmelin, 1791

Cypraea subviridis Reeve, 1835

Cypraea teres Gmelin, 1791

Family Velutinidae

Lamellaria sp.

Family Eulimidae

Melanella martinii (A. Adams, 1854)

Thyca stellasteris Koehler and Vainey, 1912

Family Epitoniidae

Cirsotrema kieneri (Tapparone-Canefri, 1876) *

Cirsotrema bavayi (de Boury, 1912)

Epitonium cf. pallasi Kiener, 1838 
Family Naticidae

Natica collei Récluz, 1844

Natica euzona Récluz, 1844 *

Natica simplex Schepman, 1909

Natica vitellus (Linnaeus, 1758)

Naticasp.

Eunaticina papilla (Gmelin, 1791)

Polinices powisiana (Récluz, 1844)

Polinices simiae (Deshayes, 1838) *

Sinum haliotoideum (Linnaeus, 1758)

\section{Family Ranellidae}

Cymatium labiosum (Wood, 1828)

Cymatium pfefferianum (Reeve, 1844) *

Cymatium vespaceum (Lamarck, 1822)

Cymatium sp.

Cymatium (Ranularia) cynocephalum (Lamarck, 1816) *

Cymatium (Monoplex) thersites (Reeve, 1844)

Gyrineum caudatum (Gmelin, 1791)

Gyrineum lacunatum (Mighels, 1845)

Biplex pulchellum (Sowerby, 1825)

Family Bursidae

Bursa granularis (Röding, 1798)

Bursa rana (Linnaeus, 1758)

Bufonaria margariticola (Deshayes, 1832) *

Family Cassidae

Phalium bandatum (Perry, 1811)

Semicassis angasi (Iredale, 1927) *

\section{Family Ficidae}

Ficus eopsila (Peron, 1807) *

Ficus subintermedia (Orbigny, 1852)

Family Tonnidae

Tonna variegata (Lamarck, 1822) *

Tonna zonata (Green, 1830) *

\section{Family Muricidae}

Chicoreus banksii (Sowerby, 1841)

Chicoreus cervicornis (Lamarck, 1822)

Chicoreus cornucervi (Röding, 1798)

Hexaplex stainforthi (Reeve, 1842)

Haustellum multiplicatus (Sowerby, 1895)

Murex acanthostephes Watson, 1883

Murex brevispina macgillivrayi Dohrn, 1862

Murex pecten soelae Ponder and Vokes, 1988

Orania ficula (Reeve, 1848) *

Pterynotus pinnatus (Swainson, 1822) *

Pterynotus acanthopterus (Lamarck, 1816)

Pterynotus akation Vokes, 1993

Rapana rapiformis (Born, 1778)

Thais echinata (Blainville, 1832)

Cronia avellana (Reeve, 1846)

Cronia margariticola (Broderip, 1833)

Morula spinosa (H. and A. Adams, 1853)

Family Coralliophilidae

Coralliophila costularis (Lamarck, 1816)

Family Nassariidae

Cyllene sulcata Sowerby, 1859

Nassarius albinus (Thiele, 1930) *

Nassarius algidus (Reeve, 1853)

Nassarius bicallosus (Smith, 1876)

Nassarius comptus (A. Adams, 1852)
Nassarius conoidalis (Deshayes, 1832)

Nassarius glans (Linnaeus, 1758)

Nassarius pauperus (Gould, 1850)

Nassarius sinusigerus (A. Adams, 1852)

Family Buccinidae

Cantharus erythrostoma (Reeve, 1846)

Colubraria sp.

Phos sculptilis Watson, 1886

Phos senticosus (Linnaeus, 1758)

Family Fasciolariidae

Dolicholatirus sp.

Fusinus colus (Linnaeus, 1758)

Latirus craticulatus (Linnaeus, 1758)

Latirus paetelianus (Kobelt, 1876)

Latirus sp.

\section{Family Costellariidae}

Vexillum cf. coronatum (Helbling, 1779)*

Vexillum modestum (Reeve, 1845) *

Vexillum cf. obeliscus (Reeve, 1844)

Vexillum unifasciatum (Wood, 1828) *

Vexillum vulpecula (Linnaeus, 1758) *

Vexillum sp.

Family Mitridae

Mitra fraga Quoy and Gaimard, 1833 *

Mitra gilbertsoni (J. Cate, 1968)

Mitra rosacea Reeve, $1845^{*}$

Mitra variabilis Reeve, 1844

Cancilla praestantissima (Röding, 1798)

Neocancilla circula (Kiener, 1838) *

Neocancilla?sp. *

Scabricola coriacea (Reeve, 1845)

Ziba flammea (Quoy and Gaimard, 1833)

Ziba interlirata (Reeve, 1844) *

Family Harpidae

Harpa articularis Lamarck, 1822 *

Harpa sp.

Family Olividae

Ancillista cingulata (Sowerby, 1830) *

Ancillista muscae (Pilsbry, 1926)

Ancillista velesiana Iredale, 1936 *

Oliva brettinghami Bridgman, 1909

Oliva panniculata Duclos, 1835

Oliva sp.

Family Turbinellidae

Syrinx aruanus (Linnaeus, 1758)

Tudivasum inermis Angas, 1878

Family Volutidae

Amoria dampieria Weaver, 1960

Amoria ellioti (Sowerby, 1864) *

Amoria grayi Ludbrook, 1953

Amoria jamrachi Gray, 1864 *

Amoria praetexta (Reeve, 1849)

Cymbiola oblita (Smith, 1909)

Melo amphora (Lightfoot, 1786)

Volutoconus hargreavesi (Angas, 1872)

Family Cancellariidae

Cancellaria melanostoma westralis (Sowerby, 1849)

Cancellaria cf. panamuna Garrard, 1975 
Table 1 (cont.)

Trigonostoma amasia (Iredale, 1930)

Trigonostoma scalare (Gmelin, 1791)

Trigonostoma scalarina (Lamarck, 1822)

Trigonostoma textilis (Kiener, 1841)

\section{Family Turridae}

Gemmula dampieriana Powell, 1964

Lophiotoma acuta (Perry, 1811)

Lophiotoma indica (Röding, 1798)

Lophiotomasp.

Turris crispa (Lamarck, 1816)

Xenuroturtis millepunctata (Sowerby, 1908)

Turricula granobalteatus (Hedley, 1922)

Tomopleura cf. cicatrigula (Hedley, 1922)

Inquisitor cf. dampierius (Hedley, 1922)

Inquisitor cf. flindersianus (Hedley, 1922)

Inquisitor formidabilis (Hedley, 1922) *

Inquisitor intertincta (Smith, 1877)

Inquisitor spicata (Hinds, 1843) *

Funa sp. A

Funa sp. B

Ptychobela crenularis (Lamarck, 1816)

Crassispira sp.

Vexitomina sp.

Cerodrillia sp.

Daphnella cf. subula (Reeve, 1845)

Etrema cf. acricula (Hedley, 1922)

Eucithara sp.

\section{Family Conidae}

Conus dampieriensis Coomans and Filmer, 1985

Conus longurionis Kiener, 1845 *

Conus reductaspiralis Walls, 1979

Conus spectrum Linnaeus, 1758 *

Conus suturatus Reeve, 1844

Conus trigonus Reeve, 1848

Family Terebridae

Duplicaria australis (Smith, 1873) *

Terebra bathyraphe Smith, 1875

Terebra commaculata (Gmelin, 1791) *

Terebra cingulifera Lamarck, 1822 *

Terebra exiguoides Schepman, 1913
Terebra marmorata Deshayes, 1859

Terebra nitida Hinds, 1844

Terebra polygyrata Deshayes, 1859

Terebra textilis Hinds, 1844

Terebra walkeri E. A, Smith, 1899

Terebra sp.

Family Pyramidellidae

Pyramidella acus (Gmelin, 1791)

Family Atyidae

Atys sp.*

Family Scaphanderidae

Cylichna sp *

Family Hydatinidae

Hydatina albocincta (van der Hoven, 1839) *

Family Pleurobranchidae

Pleurobranchus sp.

Euselenops cf. Iuniceps (Cuvier, 1817)

Family Dorididae

Discodoris sp.

Platyodoris sp.

Trippa intecta (Kelaart, 1858)

Family Chromodorididae

Ceratosoma trilobataum (Gray, 1827)

Chromodoris sp.

Family Arminidae

Armina cf. cygnea (Bergh, 1876)

POLYPLACOPHORA

Notoplax jaubertensis (Ashby, 1924)

Chiton (Rhyssoplax) sp.

Callistochiton sp.

BRACHIOPODA

Discinisca sp. 
Table 2 Ranked abundance of the most common living molluscs $(\mathrm{N}=4433)$.

\begin{tabular}{lll}
\hline Species & N & $\%$ \\
\hline Melaxinaea vitrea & 543 & 12.2 \\
Corbula tunicata & 261 & 5.9 \\
Corbula crassa & 256 & 5.8 \\
Herpetopoma atrata & 242 & 5.5 \\
Xenophora solarioides & 156 & 3.5 \\
Trisidos semitorta & 143 & 3.2 \\
Placamen calophyllum & 111 & 2.5 \\
Archimediella fastigiata & 99 & 2.2 \\
Strombus vittatus vittatus & 85 & 1.9 \\
Anadara hubbardi & 70 & 1.6 \\
Oliva brettinghami & 67 & 1.5 \\
Tucetona odhneri & 59 & 1.3 \\
Venericardia cardioides & 54 & 1.2 \\
Chicoreus cervicornis & 53 & 1.2 \\
Haustator cingulifera & 48 & 1.1 \\
Phos senticosus & 45 & 1.0 \\
Tudivasum inermis & 44 & 1.0 \\
Malleus albus & 44 & 1.0 \\
Strombus campbelli & 43 & 1.0 \\
Plicatula chinensis & 43 & 1.0 \\
Acarplicata & 39 & 0.9 \\
Gastrochaena gigantea & 39 & 0.9 \\
Lophiotoma indica & 37 & 0.8 \\
Lithophaga teres & 37 & 0.8 \\
Dendrostrea folium & 37 & 0.8 \\
\hline
\end{tabular}

Table 3 Summary data and indicator species for the station groups from the Bray-Curtis analysis (Figure 4). Miscellaneous stations of Group A not included.

\begin{tabular}{|c|c|c|c|c|c|c|c|c|}
\hline Group & B & C1 & $\mathrm{C} 2$ & C3 & $\mathrm{D}$ & E & F & $\mathrm{G}$ \\
\hline $\begin{array}{l}\text { Number of } \\
\text { stations }\end{array}$ & 6 & 7 & 7 & 9 & 14 & 15 & 20 & 5 \\
\hline $\begin{array}{l}\text { Number of } \\
\text { species }\end{array}$ & 69 & 72 & 44 & 78 & 161 & 81 & 167 & 25 \\
\hline $\begin{array}{l}\text { Average } \\
\text { similarity }\end{array}$ & 22.68 & 19.63 & 24.4 & 27.10 & 23.00 & 14.3 & 24.50 & 17.96 \\
\hline \multirow[t]{10}{*}{$\begin{array}{l}\text { Indicator } \\
\text { Species }\end{array}$} & $\begin{array}{l}\text { Chama } \\
\text { lazarus }\end{array}$ & $\begin{array}{l}\text { Corbula } \\
\text { tunicata }\end{array}$ & $\begin{array}{l}\text { Tudivasum } \\
\text { inermis }\end{array}$ & $\begin{array}{l}\text { Corbula } \\
\text { tunicata }\end{array}$ & $\begin{array}{l}\text { Corbula } \\
\text { tunicata }\end{array}$ & $\begin{array}{l}\text { Xenophora } \\
\text { solarioides }\end{array}$ & $\begin{array}{l}\text { Melaxinaea } \\
\text { vitrea }\end{array}$ & $\begin{array}{l}\text { Placamen } \\
\text { calophyllum }\end{array}$ \\
\hline & $\begin{array}{l}\text { Acar } \\
\text { plicata }\end{array}$ & $\begin{array}{l}\text { Cronia } \\
\text { avellana }\end{array}$ & $\begin{array}{l}\text { Corbula } \\
\text { tunicata }\end{array}$ & $\begin{array}{l}\text { Herpetoma } \\
\text { atrata }\end{array}$ & $\begin{array}{l}\text { Chicoreus } \\
\text { cervicornis }\end{array}$ & $\begin{array}{l}\text { Melaxinaea } \\
\text { vitrea }\end{array}$ & $\begin{array}{l}\text { Corbula } \\
\text { crassa }\end{array}$ & $\begin{array}{l}\text { Lophiotoma } \\
\text { indica }\end{array}$ \\
\hline & $\begin{array}{l}\text { Hiatella } \\
\text { australis }\end{array}$ & $\begin{array}{l}\text { Gastrochaena } \\
\text { gigantea }\end{array}$ & $\begin{array}{l}\text { Xenophora } \\
\text { solarioides }\end{array}$ & $\begin{array}{l}\text { Xenophora } \\
\text { solarioides }\end{array}$ & $\begin{array}{l}\text { Conus } \\
\text { dampieriensis }\end{array}$ & $\begin{array}{l}\text { Natica } \\
\text { vitellus }\end{array}$ & $\begin{array}{l}\text { Placamen } \\
\text { calophyllum }\end{array}$ & $\begin{array}{l}\text { Haustator } \\
\text { cingulifera }\end{array}$ \\
\hline & $\begin{array}{l}\text { Herpetoma } \\
\text { atrata }\end{array}$ & $\begin{array}{l}\text { Herpetoma } \\
\text { atrata }\end{array}$ & $\begin{array}{l}\text { Fusinus } \\
\text { colus }\end{array}$ & $\begin{array}{l}\text { Malleus } \\
\text { albus }\end{array}$ & $\begin{array}{l}\text { Phos } \\
\text { senticosus }\end{array}$ & $\begin{array}{l}\text { Limopsis } \\
\text { multistriata }\end{array}$ & $\begin{array}{l}\text { Trisidos } \\
\text { semitorta }\end{array}$ & $\begin{array}{l}\text { Herpetoma } \\
\text { atrata }\end{array}$ \\
\hline & $\begin{array}{l}\text { Thais } \\
\text { echinata }\end{array}$ & $\begin{array}{l}\text { Lithophaga } \\
\text { malaccana }\end{array}$ & $\begin{array}{l}\text { Gemmula } \\
\text { dampieriana }\end{array}$ & $\begin{array}{l}\text { Placamen } \\
\text { tiara }\end{array}$ & $\begin{array}{l}\text { Venericardia } \\
\text { cf cardioides }\end{array}$ & $\begin{array}{l}\text { Malleus } \\
\text { albus }\end{array}$ & $\begin{array}{l}\text { Anadara } \\
\text { hubbardi }\end{array}$ & \\
\hline & $\begin{array}{l}\text { Lima } \\
\text { nimbifer }\end{array}$ & $\begin{array}{l}\text { Malvufundus } \\
\text { regula }\end{array}$ & $\begin{array}{l}\text { Strombus } \\
\text { plicatus } \\
\text { pulchellus }\end{array}$ & $\begin{array}{l}\text { Plicatula } \\
\text { chinensis }\end{array}$ & $\begin{array}{l}\text { Strombus } \\
\text { campbelli }\end{array}$ & $\begin{array}{l}\text { Leionucula } \\
\text { superba }\end{array}$ & $\begin{array}{l}\text { Circe } \\
\text { scripta }\end{array}$ & \\
\hline & $\begin{array}{l}\text { Cronia } \\
\text { avellana }\end{array}$ & $\begin{array}{l}\text { Mimachlamys } \\
\text { "scabricostata" }\end{array}$ & $\begin{array}{l}\text { Turricula } \\
\text { granobalteatus }\end{array}$ & $\begin{array}{l}\text { Ancillista } \\
\text { muscae }\end{array}$ & $\begin{array}{l}\text { Tudivasum } \\
\text { inermis }\end{array}$ & $\begin{array}{l}\text { Plicatula } \\
\text { chinensis }\end{array}$ & $\begin{array}{l}\text { Oliva } \\
\text { brettinghami }\end{array}$ & \\
\hline & $\begin{array}{l}\text { Pteria } \\
\text { lata }\end{array}$ & $\begin{array}{l}\text { Strombus } \\
\text { campbelli }\end{array}$ & $\begin{array}{l}\text { Leionucula } \\
\text { superba }\end{array}$ & $\begin{array}{l}\text { Strombus } \\
\text { campbelli }\end{array}$ & $\begin{array}{l}\text { Tucetona } \\
\text { odhneri }\end{array}$ & $\begin{array}{l}\text { Clathrotellina } \\
\text { elegantissima }\end{array}$ & $\begin{array}{l}\text { Chicoreus } \\
\text { cervicornis }\end{array}$ & \\
\hline & $\begin{array}{l}\text { Mimachlamys } \\
\text { "scabricostata" }\end{array}$ & $\begin{array}{l}\text { Limaria } \\
\text { fragilis }\end{array}$ & $\begin{array}{l}\text { Distorsio } \\
\text { reticulata }\end{array}$ & $\begin{array}{l}\text { Tucetona } \\
\text { angusticosta }\end{array}$ & $\begin{array}{l}\text { Herpetoma } \\
\text { atrata }\end{array}$ & $\begin{array}{l}\text { Pteria } \\
\text { cookei }\end{array}$ & $\begin{array}{l}\text { Nassarius } \\
\text { comptus }\end{array}$ & \\
\hline & $\begin{array}{l}\text { Scutus } \\
\text { unguis }\end{array}$ & $\begin{array}{l}\text { Acar } \\
\text { plicata }\end{array}$ & $\begin{array}{l}\text { Xenophora } \\
\text { cerea }\end{array}$ & $\begin{array}{l}\text { Dosinia } \\
\text { deshayesii }\end{array}$ & $\begin{array}{l}\text { Cantharus } \\
\text { erythrostoma }\end{array}$ & $\begin{array}{l}\text { Phos } \\
\text { senticosus }\end{array}$ & $\begin{array}{l}\text { Turricula } \\
\text { granobalteus }\end{array}$ & \\
\hline
\end{tabular}


Stations

\section{Species}

$\begin{array}{llllllll}1 & 2 & 3 & 4 & 5 & 6 & 7 & 8\end{array}$

$9 \quad 10 \quad 11$

$12 \quad 13 \quad 15$

Scutus unguis

Diodora jukesii

Diodora singaporensis

Diodora ticaonica

Tugali cicatricosa

Trochus schlueteri

Notogibbula sp.

Calthalotia mundula

Calthalotia sp.

Stomatia phymotis

Calliostoma monile

Clanculus bicarinatus

Clanculus comarilis

Turcica maculata

Euchelus sp.

Herpetopoma instricta

Monilea callifera

Herpetoma atrata

Turbohaynesi

Astralium stellare

Cerithium novaehollandiae

Cerithium torresi

Rhinoclavis articulata

Rhinoclavis kochi

Haustator cingulifera

Archimediella fastigiata

Strombus vittatus vittatus

Strombus campbelli

Strombus dilatatus

Strombus plicatus pulchellus

Rimella cancellata

Terebellum terebellum

Crepidula aculeata

Hipponix sp.

Siliquaria sp.

Vanikoro cancellata

Xenophora indica

Xenophora cerea

Xenophora solarioides

Cypraea subviridis

21

11

$\begin{array}{ll} & 1 \\ 1 & 1\end{array}$

1
1

5

\section{1}

1 
Phenacovolva haynesi

Hiatovolva depressa

Phenacovolva philippinarum

Prionovula cavanaghi

Diminovula ?alabaster

Primovula striatula

Lamellaria sp.

Polinices powisiana

Natica simplex

Natica vitellus

Natica collei

Eunaticina papilla

Sinum hatiotoideum

Bursa granularis

Bursa rana

Cymatium vespaceum

Gyrineum lacunatum

Cymatium labiosum

Cymatium sp.

Biplex pulchellum

Ficus subintermedia

Distorsio reticulata

Phalium bandatum

Epitonium pallasi

Cirsotrema bavayi

Thyca stellasteris

Melanella martini

Murex brevispina macgillivrayi

Murex pecten soelae

Haustellum multiplicatus

Murex acanthostephes

Chicoreus banksii

Chicoreus cervicornis

Chicoreus cornucervi

Rapana rapiformis

Pterynotus acanthopterus

Pterynotus akation

Hexaplex stainforthi

Thais echinata

Cronia avellana

Cronia margaritcola

Morula spinosa 
Stations

\section{Species}

Coralliophila costularis

Phos sculptilis

Colubrariasp.

Cantharus erythrostoma

Phos senticosus

Tudivasum inermis

Syrinx aruanus

Fusinus colus

Latirus paetelianus

Latirus sp.

Dolicholatirus sp.

Nassarius algidus

Nassarius bicallosus

Nassarius comptus

Nassarius conoidalis

Nassarius glans

Nassarius pauperus

Nassarius sinusigerus

Cyllene sulcata

Amoria dampieria

Amoria grayi

Amoria praetexta

Cymbiola oblita

Volutoconus hargreavesi

Melo amphora

Ancillista muscae

Oliva brettingham

Oliva panniculata

Mitra gilbertson

Mitra variablis

Cancilla praestantissima

Scabricola coriacea

Ziba flammea

Harpa sp.

Vexillum cf. obeliscus

Vexillum sp.

Trigonostoma amasia

Trigonostoma scalare

Trigonostoma scalarina

Trigonostoma textilis

$\begin{array}{llllllllllllllll}1 & 2 & 3 & 4 & 5 & 6 & 7 & 8 & 9 & 10 & 11 & 12 & 13 & 15 & 16 & 17\end{array}$

1

$\begin{array}{llllllllll} & & & 1 & 1 & & & 2 & & \\ & 2 & & 2 & 3 & & & & \\ & 1 & 1 & & 1 & 1 & & \\ & 1 & & & & & & \\ 1 & 1 & & & & & 1 & 1\end{array}$

$\begin{array}{llllll}21 & 22 & 23 & 24 & 25 & 26\end{array}$

$\begin{array}{llllll}27 & 28 & 29 & 30 & 31 & 32\end{array}$

1

11 
Cancellaria melanostoma westralis

Cancellaria panamuna

Conus dampieriensis

Conus trigonus

Conus suturatus

Terebra bathyraphe

Terebra exiguoides

Terebra marmorata

Terebra nitida

Terebra textilis

Lophiotoma acuta

Lophiotoma indica

Lophiotomasp.

Turris crispa

Gemmula dampieriana

Xenuroturris millepunctata

Turricula granobalteatus

Ptychobela suturalis

1

Funa sp. A

Funa sp. B

Inquisitor cf. damperius

Inquisitor cf. flindersiana

Inquisitor cf. intertincta

Cerodrillia sp.

Etrema cf. acricula

Daphnella cf. subula

Eucithara sp.

Pyramidella acus

Cylichna sp.

Euselenops cf. luniceps

Pleurobranchussp.

Hexabranchus sanguineus

Ceratosoma trilobatum

Armina cygnea

Trippa intecta

Chromodoris sp.

Discodoris sp.

Platydoris sp.

Total gastropods

$\begin{array}{lllllllllllll}6 & 1 & 8 & 15 & 5 & 15 & 23 & 13 & 5 & 13 & 1 & 11 & 26\end{array}$

$\begin{array}{lll}14 & 57 & 7\end{array}$

43

$15 \quad 13$

14

15

21

10 
Stations

Species

Scutus unguis

Diodora jukesii

Diodora singaporensis

Diodora ticaonica

Tugali cicatricosa

Trochus schlueteri

Notogibbula sp.

Calthalotia mundula

Calthalotia sp.

Stomatia phymotis

Calliostoma monile

Clanculus bicarinatus

Clanculus comarilis

Turcica maculata

Euchelus sp.

Herpetopoma instricta

Monilea callifera

Herpetoma atrata

Turbohaynesi

Astralium stellare

Cerithitum novaehollandiae

Cerithium torresi

Rhinoclavis articulata

Rhinoclavis kochi

Haustator cingulifera

Archimediella fastigiata

Strombus vittatus vittatus

Strombus campbelli

Strombus dilatatus

Strombus plicatus pulchellus

Rimella cancellata

Terebellum terebellum

Crepidula aculeata

Hipponix sp.

Siliquaria sp.

Vanikoro cancellata

Xenophora indica

Xenophora cerea

Xenophora solarioides

Cypraea subviridis

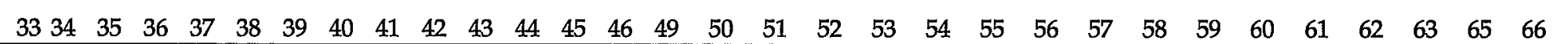

1


Cypraea teres

Cypraea gracilis

Phenacovolva haynesi

Phenacovolva philippinarum

Prionovula cavanaghi

Diminovula ?alabaster

Primovula striatula

Lamellaria sp.

Polinices powisiana

Natica simplex

Natica vitellus

Natica collei

Eunaticina papilla

Sinum hatiotoideum

Bursa granularis

Bursa rana

Cymatium vespaceum

Gyrineum lacunatum

Cymatium labiosum

Cymatium sp.

Biplex pulchellum

Ficus subintermedia

Distorsio reticulata

Phalium bandatum

Epitonium pallasi

Cirsotrema bavayi

Thyca stellasteris

Melanella martinii

Murex brevispina macgillivrayi

Murex pecten soelae

Haustellum multiplicatus

Murex acanthostephes

Chicoreus banksii

Chicoreus cervicornis

Chicoreus cornucervi

Rapana rapiformis

Pterynotus acanthopterus

Pterynotus akation

Hexaplex stainforthi

Thais echinata

Cronia avellana

Cronia margaritcola

Morula spinosa 
Stations

Species

Coralliophila costularis

Phos sculptilis

Colubraria sp.

Cantharus erythrostoma

Phos senticosus

Tudivasum inermis

Syrinx aruanus

Fusinus colus

Latirus paetelianus

Latirus sp.

Dolicholatirus sp.

Nassarius algidus

Nassarius bicallosus

Nassarius comptus

Nassarius conoidalis

Nassarius glans

Nassarius pauperus

Nassarius sinusigerus

Cyllene sulcata

Amoria dampieria

Amoria grayi

Amoria praetexta

Cymbiola oblita

Volutoconus hargreavesi

Melo amphora

Ancillista muscae

Oliva brettingham

Oliva panniculata

Mitra gilbertsoni

Mitra variablis

Cancilla praestantissima

Scabricola coriacea

Ziba flammea

Harpa sp.

Vexillum cf. obeliscus

Vexillum $\mathrm{sp}$.

Trigonostoma amasia

Trigonostoma scalare

Trigonostoma scalarina

Trigonostoma textilis

Cancellaria melanostoma westralis

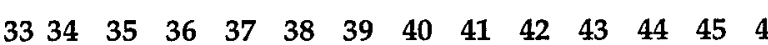

0

53

$55 \quad 56$

\begin{tabular}{lll}
57 & $58 \quad 59$ \\
\hline
\end{tabular}

$\begin{array}{llllll}60 & 61 & 62 & 63 & 65 & 66\end{array}$

1

1

2

11

$\begin{array}{lllll}4 & & & 3 & 1 \\ 2 & 2 & & 7 & 3 \\ & & & 1 & \\ & & 1 & 1 & \end{array}$

1
1

$32-2$

1

$\begin{array}{rr}1 & 1 \\ 1 \\ 1\end{array}$

1

2 
Conus suturatus

Terebra bathyraphe

Terebra exiguoides

Terebra marmorata

Terebra nitida

Terebra textilis

Lophiotoma acuta

Lophiotoma indica

Lophiotomasp.

Turris crispa

Gemmula dampieriana

Xenuroturris millepunctata

Turricula granobalteatus

Ptychobela suturalis

Ptycholbela crenularis

Funa sp. A

Funa sp. B

Inquisitor cf. damperius

Inquisitor cf. flindersiana

Inquisitor cf. intertincta

Cerodrillia sp.

Etrema cf. acricula

Daphnella cf. subula

Eucithara sp.

Pyramidella acus

Cylichna sp.

Euselenops cf. luniceps

Pleurobranchus sp.

Hexabranchus sanguineus

Ceratosoma trilobatum

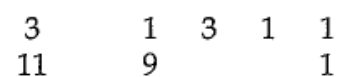

1

2

$5 \quad 1$

Chromodorissp.

Discodoris sp.

$\begin{array}{lllllllll}29 & 63 & 13 & 27 & 28 & 88 & 21 & 11 & 30\end{array}$

$\begin{array}{lll}13 & 12 & 14\end{array}$

$\begin{array}{lll}2 & 18 & 35\end{array}$

81

$\begin{array}{llll}48 & 43 & 17 & 30\end{array}$

$\begin{array}{llll}30 & 9 & 7 & 16\end{array}$ 
Stations

Diodora singaporensis

Tugali cicatricosa

Trochus schlueteri

Notogibbula sp.

Calthalotia mundula

Calthalotiasp.

Stomatia phymotis

Calliostoma monile

Clanculus bicarinatus

Clanculus comarilis

Turcica maculata

Euchelus sp.

Herpetopoma instricta

Monilea callifera

Herpetoma atrata

Turbo haynesi

Astralium stellare

Cerithium novaehollandiae

Cerithium torresi

Rhinoclavis articulata

Rhinoclavis kochi

Haustator cingulifera

Archimediella fastigiata

Strombus vittatus vittatus

Strombus campbelli

Strombus dilatatus

Strombus plicatus pulchellus

Rimella cancellata

Terebellum terebellum

Crepidula aculeata

Hipponixsp.

Siliquaria sp.

Vanikoro cancellata

Xenophora indica

Xenophora cerea

Xenophora solarioides

Cypraea subviridis

Cypraea miliaris
181
1
25

1

1

1

$\begin{array}{lllllll}1 & 11 & 2 & 86 & 6 & 1 & 2\end{array}$

38

$\begin{array}{ll}5 & 1\end{array}$

1

2
18

$2 \quad 2$
1 
Primovula striatula

Lamellaria sp.

Polinices powisiana

Natica simplex

Natica vitellus

Natica collei

Eunaticina papilla

Sinum hatiotoideum

Bursa granularis

Bursa rana

Cymatium vespaceum

Gyrineum lacunatum

Cymatium labiosum

Cymatium sp.

Biplex pulchellum

Ficus subintermedia

Distorsio reticulata

Phalium bandatum

Epitonium pallasi

Cirsotrema bavayi

Thyca stellasteris

Melanella martinii

Murex brevispina macgillivrayi

Murex pecten soelae

Haustellum multiplicatus

Murex acanthostephes

Chicoreus banksil

Chicoreus cervicornis

Chicoreus cornucero

Rapana rapiformis

Pterynotus acanthopterus

Pterynotus akation

Hexaplex stainforthi

Thais echinata

Cronia avellana

Cronia margaritcola

Morula spinosa

Coralliophila costularis

1
1

1

1

1

$\begin{array}{ll}1 & 1 \\ & 1\end{array}$


Stations

Species

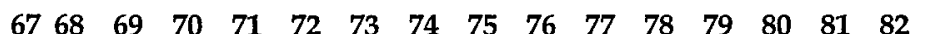

Phos sculptilis

10

Colubraria sp.

Cantharus erythrostoma

Phos senticosus

Tudivasum inermis

Syrinx aruanus

Fusinus colus

Latirus paetelianus

Latirus sp.

Dolicholatirus sp.

Nassarius algidus

Nassarius bicallosus

Nassarius comptus

Nassarius conoidalis

Nassarius glans

Nassarius pauperus

Nassarius sinusigerus

Cyllene sulcata

Amoria dampieria

Amoria grayi

1

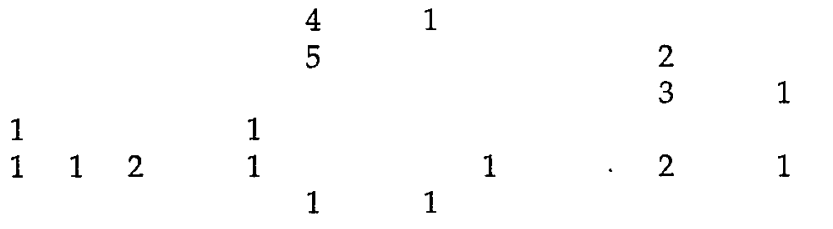

Amoria praetexta

Cymbiola oblita

Volutoconus hargreavesi

Melo amphora

Ancillista muscae

Oliva brettingham

Oliva panniculata

Mitra gilbertsoni

Mitra variablis

Cancilla praestantissima

Scabricola coriacea

Ziba flammea

Harpa sp.

Vexillum cf. obeliscus

Vexillum sp.

Trigonostoma amasia

Trigonostoma scalare

Trigonostoma scalarin

Trigonostoma textilis

Cancellaria melanostoma westralis
4

$\begin{array}{llll}3 & 1 & 1\end{array}$

11

1
1 
Conus suturatus

Terebra bathyraphe

Terebra exiguoides

Terebra marmorata

Terebra nitida

Terebra textilis

Lophiotoma acuta

Lophiotoma indica

Lophiotoma sp.

Turricula granobalteatus

Ptychobela suturalis

Ptycholbela crenularis

Funa sp. A

Funa sp. B

Inquisitor cf. damperius

Inquisitor cf. flindersiana

Inquisitor cf. intertincta

Cerodrillia sp.

Etrema cf. acricula

Daphnella cf. subula

Eucithara sp.

Pyramidella acus

Cylichna sp.

Euselenops cf. luniceps

Pleurobranchus sp.

Hexabranchus sanguineus

Ceratosoma trilobatum

Armina cygnea

Trippa intecta

Chromodoris sp.

Discodoris sp.

Platydoris sp.

$\begin{array}{lll}1 & 1 & 1\end{array}$ 
Stations

Bivalvia

$\begin{array}{llllll}1 & 2 & 3 & 4 & 5 & 2\end{array}$

$1920 \quad 21$

$\begin{array}{lllll}22 & 23 & 24 & 25 & 26\end{array}$

$27 \quad 28$

29

$31 \quad 32$

Leionucula superba

Arca avellana

1

1

2

Arca navicularis

Arca ventricosa

Anadara hubbardi

Barbatia cf. foliata

Barbatia cf. bistrigata

Trisidos semitorta

Acar plicata

Acar cf. riculata

Cucullaea labiata

Tucetona angusticosta

Tucetona odhneri

Melaxinaea vitrea

Limopsis multistriata

Stavelia subdistorta

Modiolus cf. barbatus

Modiolus philippinarum

Modiolatus elongatus

Septifer bilocularis

Musculus cf. cumingianus

Botula silicula

Gregariella otteri

Lithophaga lima

Lithophaga malaccana

Lithophaga teres

Pteria cookei

Pteria falcata

Pteria lata

Pteria penguin

Pteria sp.

Pinctada maxima

Electroma spadicea

Pterelectroma physoides

Malleus albus

Malvufundus regula

Vulsella vulsella

Isognomon legumen

$\begin{array}{lll}1 & 1 & 1\end{array}$

Atrina pectinata

Pinna sp.

Annachlamys flabellata

10

$\begin{array}{lll}10 & 10 \quad 9\end{array}$

1

11

1

41

$\begin{array}{llll}1 & & & 4 \\ 1 & & 1 & \\ & 1 & & 1 \\ & 9 & & 1\end{array}$

1

5
5 
topecten nix

Hemipecten forbesianus

Spondylus albibarbatus Spondylus eastae

Spondylus wrightianus

Spondylus sp. B

Lima nimbifer

Limaria fragilis

Limaria sp.

Hyotissa hyotis

Dendrostrea folium

Planostrea cf. pestigris

Plicatula australis

Plicatula chinensis

Monia sp.

Placuna lobata

Neotrigonia bednalli

Neotrigonia uniophora

Lamellolucina pilbara

Cardiolucina pisiformis

Diplodonta cf. holosphaera

Scintilla cf. aurantia

Scintilla spp

Galeomma sp.

Ephippodonta sp.

Lepton sp.

Talabrica ziczac

Eucrassatella pulchra

Salaputium rhomboides

Venericardia cardioides

Cardita crassicosta

Cardita incrassata

Cardita variegata

Chama asperella

Chama lazarus

Chama pacifica

Chama sp.

Vepricardium multispinosum

Nemocardium bechei

1

3

Acrosterigma rosemariensis 
Stations

Bivalvia

$\begin{array}{llllllllllllll}1 & 2 & 3 & 4 & 5 & 6 & 7 & 8 & 9 & 10 & 11 & 12 & 13 & 15\end{array}$

17

$\begin{array}{lll}8 & 19 & 20\end{array}$

$21 \quad 22$

23

2526

$27 \quad 28$

$\begin{array}{lll}30 & 31 & 32\end{array}$

Lunulicardia retusa

Mactra incarnata

Coralliophaga coralliophaga

Arcopella cf. isseli

Arcopaginula inflata

Clathrotellina elegantissima

Clathrotellina pretium

Tellinella verrucosa

Tellinella asperrima

Tellinides ovalis

Pinguitellina casta

Semele casta

Gari amethystus

Gari anomala

Gari maculosa

Gari pulcherrima

Gari rasilis

Ensiculus cultellus

Solen sp.

Solen siphons

Antigona lamellaris

Sunetta contempta

Placamen calophyllum

Placamen tiara

Dosinia deshayesii

Dosinia cf. juvenilis

Dosinia cf. subalata

Callista cf. roseotincta

Tawera laticostata

Paphia gallus

Paphia semirugata

Circe scripta

Pitar sp.

Pitar cf. trevori

Lioconcha fastigiata

Tapes platyptycha

Callista planatella

Irus irus

Corbula crassa

Corbula macgillivrayi

2 


\section{Corbula taheitensis}

Corbula tunicata

Parapholas quadrizonata

Jouannetia cumingi

Gastrochaena dentifera

Gastrochaena gigantea

Spengleria plicatilis

Cucurbitula cymbium

Hiatella australis

Sphenia rueppellii

Laternula cf. anatina

Myadora pavimenta

Cleidothaerus plicifera

Brechites vaginiferus australis

Total bivalves

4

Scaphopoda

Laevidentalium longitrorsum

Dentalium exmouthensis

Dentalium cf. octangulatum

$\begin{array}{lccc} & 1 & & \\ 4 & 20 & 4 & 1\end{array}$

2

$\begin{array}{llll}1 & 12 & 3 & 2\end{array}$

114

66

Polyplacaphora

Rhyssoplax sp.

Notoplax jaubertensis

Callistochiton sp.

Chitons unidentified $\begin{array}{llll}2 & 1 & 1 & 3\end{array}$

1 $\begin{array}{llllllllllllll}3 & 5 & 19 & 10 & 56 & 17 & 31 & 40 & 33 & 0 & 14 & 39 & 2 & 8\end{array}$ 
Stations

Bivalvia

$\begin{array}{lllllllllllll}33 & 34 & 35 & 36 & 37 & 38 & 39 & 40 & 41 & 42 & 43 & 44 & 45\end{array}$

Leionucula superba Arca avellana

Arca navicularis

Arca ventricosa

Anadara hubbardi

Barbatia cf. foliata

Barbatia cf. bistrigat

Trisidos semitorta

Acar plicata

Acar cf. riculata

Cucullaea labiata

Tucetona angusticosta

Tucetona odhneri

Melaxinaea vitrea

Limopsis multistriata

Stavelia subdistorta

Modiolus cf. barbatus

Modiolus philippinarum

Modiolatus elongatus

Septifer bilocularis

Musculus cf. cumingianus

Botula silicula

Gregariella otteri

Lithophaga lima

Lithophaga malaccana

Lithophaga teres

Pteria cookei

Pteria falcata

Pteria lata

Pteria pengui

Pteria sp.

Pinctada maxima

Electroma spadicea

Pterelectroma physoides

Malleus albus

Malvufindus regula

Vulsella vulsella

Isognomon legumen

Atrina pectinata

Pinna sp.

Annachlamys flabellata

$\begin{array}{llll}3 & 23 & 8 & 4\end{array}$

121
1

$\begin{array}{ll}1 & \\ & 27\end{array}$

$27 \quad 163$

1317

1

58

$59 \quad 60$

$\begin{array}{lll}61 & 62 & 63\end{array}$

$\begin{array}{lll}65 & 66 & 67\end{array}$

1

2

3

1

1

1

$\begin{array}{ll}1 & 1 \\ 1 & \end{array}$

$502209 \quad 1$

7

$\begin{array}{lllllll}3 & 31 & 6 & 4 & 1 & & \\ & & & 1 & 38 & 200\end{array}$

$\begin{array}{cccccc} & & 2 & & 1 & 1 \\ 1 & 1 & & 1 & 1 & 10\end{array}$

2

10 
Cryptopecten nux

Hemipecten forbesianus

Spondylus albibarbatus

Spondylus eastae

Spondylus wrightianus

Spondylus sp. B

Lima nimbifer

Limaria fragilis

Limaria sp.

Hyotissa hyotis

Dendrostrea folium

Planostrea cf. pestigris

Plicatula australis

Plicatula chinensis

Monia sp.

Placuna lobata

Neotrigonia bednalli

Neotrigonia uniophora

Lamellolucina pilbara

Cardiolucina pisiformis

Diplodonta cf. holosphaera

Scintilla cf. aurantia

Scintilla spp

Galeomma sp.

Ephippodonta sp.

Lepton sp.

Talabrica ziczac

Eucrassatella pulchra

Salaputium rhomboides

Venericardia cardioides

Cardita crassicosta

Cardita incrassata

Cardita variegata

Chama asperella

Chama lazarus

Chama pacifica

Chama sp.

Vepricardium multispinosum

Nemocardium bechei

Ctenocardia fornicata

Acrosterigma biradiatum

Acrosterigma dampierense

Acrosterigma rosemariensis 
Stations

Bivalvia

$\begin{array}{lllllllll}33 & 34 & 35 & 36 & 37 & 38 & 39 & 40 & 41\end{array}$

$\begin{array}{lllllll}46 & 49 & 50 & 51 & 52 & 53 & 54\end{array}$

55

$56 \quad 57$

$\begin{array}{lll}59 & 60 & 61\end{array}$

61

63

$\begin{array}{lll}65 & 66 & 67\end{array}$

Lunulicardia retusa

Mactra incarnata

Coralliophaga coralliophaga

Arcopella cf. isseli

Arcopaginula inflata

Clathrotellina elegantissima

1

Clathrotellina pretium

Tellinella verrucosa

Tellinella asperrima

Tellinides ovalis

Pinguitellina casta

Semele casta

Gari amethystus

Gari anomala

Gari maculosa

Gari pulcherrima

Gari rasilis

Ensiculus cultellus

Solen sp.

Solen siphons

Antigona lamellaris

Sunetta contempta

Placamen calophyllum

Placamen tiara

Dosinia deshayesii

Dosinia cf. juvenilis

Dosinia cf. subalata

Callista cf. roseotincta

Tawera laticostata

Paphia gallus

Paphia semirugata

Circe scripta

Pitar sp.

Pitar cf. trevori

Lioconcha fastigiata

Tapes platyptycha

Callista planatella

Irus irus

Corbula crassa

Corbula macgillivrayi

1

1

2

$\begin{array}{lllllllll}17 & 1 & 4 & 18 & 14 & 1 & 2 & \\ & & & & 2 & 1 & \\ 1 & & 1 & 1\end{array}$

5

$\begin{array}{rrrrrr} & 1 & & & \\ 1 & 2 & & 1 & & 1 \\ & 1 & & 3 & 2 & \end{array}$

2
1

$\begin{array}{llll}1 & 1 & 1 & 1\end{array}$


Parapholas quadrizonata

Jouannetia cumingi

Gastrochaena gigantea

Spengleria plicatilis

Cucurbitula cymbium

Hiatella australis

Sphenia rueppellii

Laternula cf. anatina

Myadora parimenta

Cleidothaerus plicifera

Brechites vaginiferus australis

Total bivalves

$\begin{array}{lllllll}52 & 81 & 25 & 221 & 46 & 246 & 61\end{array}$

$\begin{array}{lll}61 \quad 13 \quad 24 & \end{array}$

\section{Scaphopoda}

Laevidentalium longitrorsum

Dentalium exmouthensis

Dentalium cf. octangulatum

\section{Polyplacaphora}

Rhyssoplax sp.

Notoplax jaubertensis

Callistochiton sp.

Chitons unidentified 
Stations

Bivalvia

Leionucula superba

Arca avellana

Arca navicularis

Arca ventricosa

Anadara hubbardi

Barbatia cf. foliata

Barbatia cf. bistrigata

Trisidos semitorta

Acar plicata

Acar cf. riculata

Cucullaea labiata

Tucetona angusticosta

Tucetona odhneri

Melaxinaea vitrea

Limopsis multistriata

Stavelia subdistorta

Modiolus cf. barbatus

Modiolus philippinarum

Modiolatus elongatus

Septifer bilocularis

Musculus cf. cumingianus

Botula silicula

Gregariella otteri

Lithophaga lima

Lithophaga malaccana

Lithophaga teres

Pteria cookei

Pteria falcata

Pteria lata

Pteria penguin

Pteria sp.

Pinctada maxima

Electroma spadicea

Pterelectroma physoides

Malleus albus

Malvufundus regula

Vulsella vulsella

Isognomon legumen

Atrina pectinato

Pinna sp.

Annachlamys flabellata $\begin{array}{lllllllllllllllll}68 & 69 & 70 & 71 & 72 & 73 & 74 & 75 & 76 & 77 & 78 & 79 & 80 & 81 & 82 & 83 & 84\end{array}$

$\begin{array}{llllllll}0 & 91 & 92 & 93 & 94 & 95 & 96\end{array}$

$98 \quad 99 \quad 100$

3

$1 \quad 1$

\section{1}

1

$6 \quad 1$

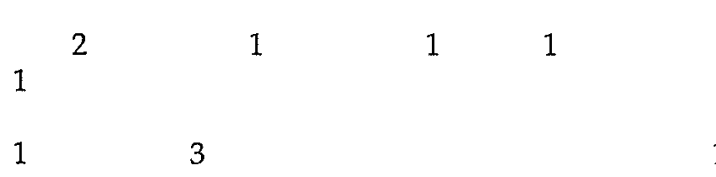

14

2

10

$2 \quad 50 \quad 500 \quad 50$

150

$2135 \begin{array}{cccc} & & 1 & 1 \\ & & 3 & 45 \\ & 1 & & \\ & & & \end{array}$

21

1

20

2011

$2 \quad 37$
1

3

1 
Complicachlamys dringi

Cryptopecten nux

Hemipecten forbesianus

Spondylus albibarbatus

Spondylus eastae

Spondylus wrightianus

Spondylus sp. B

Lima nimbifer

Limaria fragilis

Limaria sp.

Hyotissa hyotis

Dendrostrea folium

Planostrea cf. pestigris

Plicatula australis

Plicatula chinensis

Monia sp.

Placuna lobata

Neotrigonia bednalli

Neotrigonia uniophora

Lamellolucina pilbara

Cardiolucina pisiformis

Diplodonta cf. holosphaera

Scintilla cf. aurantia

Scintilla spp

Galeomma sp.

Ephippodonta sp.

Lepton sp.

Talabrica ziczac

Eucrassatella pulchra

Salaputium rhomboides

Venericardia cardioides

Cardita crassicosta

Cardita incrassata

Cardita variegata

Chama asperella

Chama lazarus

Chama pacifica

Chama sp.

Vepricardium multispinosum

Nemocardium bechei

Ctenocardia fornicata

12

11

15

1

1

3 
Stations

Bivalvia

Lunulicardia retusa

Mactra incarnata

Coralliophaga coralliophaga

Arcopella cf. issel

Arcopaginula inflata

Clathrotellina elegantissima

Clathrotellina pretium

Tellinella verrucosa

Tellinella asperrima

Tellinides ovalis

Pinguitellina casta

Semele casta

Gari amethystus

Gari anomala

Gari maculosa

Gari pulcherrima

Gari rasilis

Ensiculus cultellus

Solen sp.

Solen siphons

Antigona lamellaris

Sunetta contempta

Placamen calophyllum

Placamen tiara

Dosinia deshayesii

Dosinia cf. juvenilis

Dosinia cf. subalata

Callista cf. roseotincta

Tawera laticostata

Paphia gallus

Paphia semirugata

Circe scripta

Pitar sp.

Pitar cf. trevori

Lioconcha fastigiat

Tapes platyptycha

Callista planatella

Irus irus

Corbula crassa

Corbula macgillivray $\begin{array}{llllll}68 & 69 & 70 & 71 & 72 & 73\end{array}$

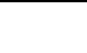

16

1

5

5

$\begin{array}{lll}98 & 99 & 100\end{array}$
1

62

5

3
1

4

21

$111-1$




\section{Corbula taheitensis \\ Corbula tunicata}

Parapholas quadrizonata

Jouannetia cumingi

Gastrochaena dentifera

Gastrochaena gigantea

Spengleria plicatilis

Cucurbitula cymbium

Hiatella australis

Sphenia rueppellii

Laternula cf. anatina

Myadora pavimenta

Cleidothaerus plicifera

Brechites vaginiferus australis

$(20)$

Total bivalves

Scaphopoda

Laevidentalium longitrorsum

Dentalium exmouthensis

Dentalium cf. octangulatum
2
163

8

$4 \quad 16$

22

1

$\begin{array}{llll}47 & 62 & 34 & 2\end{array}$

$\begin{array}{lll}65 & 126 & 14\end{array}$

$\begin{array}{lllll}21 & 16 & 7 & 15 & 10\end{array}$

$\begin{array}{ll}0 & 1\end{array}$

$\begin{array}{lll}4 & 33\end{array}$

$\begin{array}{ll}0 & 5\end{array}$

9

$\begin{array}{llll}5 & 25 & 98 & 519\end{array}$

$\begin{array}{llllll}64 & 43 & 23 & 198 & 23 & 0\end{array}$

Polyplacaphora

Rhyssoplax sp.

Notoplax jaubertensis

Callistochiton sp.

Chitons unidentified

2

1

1
1

1 